\title{
Article \\ The Economic Effect of the Pandemic in the Energy Sector on the Example of Listed Energy Companies
}

\author{
Edyta Rutkowska-Tomaszewska ${ }^{1}$, Aleksandra Łakomiak ${ }^{2, *(1)}$ and Marta Stanisławska ${ }^{3}$ \\ 1 Faculty of Law, Administration and Economics, University of Wroclaw, 50-137 Wroclaw, Poland; \\ edyta.rutkowska-tomaszewska@uwr.edu.pl \\ 2 The Faculty of Business and Management, Wroclaw University of Economics and Business, \\ 53-345 Wroclaw, Poland \\ 3 Faculty of Technical and Economic Sciences, Witelon State University of Applied Sciences in Legnica, \\ 59-220 Legnica, Poland; mmstanislawska@gmail.com \\ * Correspondence: aleksandra.lakomiak@ue.wroc.pl
}

Citation: Rutkowska-Tomaszewska, E.; Łakomiak, A.; Stanisławska, M. The Economic Effect of the Pandemic in the Energy Sector on the Example of Listed Energy Companies. Energies 2022, 15, 158. https://doi.org/ 10.3390/en15010158

Academic Editors: Jin-Li Hu and Behnam Zakeri

Received: 18 November 2021

Accepted: 23 December 2021

Published: 27 December 2021

Publisher's Note: MDPI stays neutral with regard to jurisdictional claims in published maps and institutional affiliations.

Copyright: (C) 2021 by the authors. Licensee MDPI, Basel, Switzerland. This article is an open access article distributed under the terms and conditions of the Creative Commons Attribution (CC BY) license (https:// creativecommons.org/licenses/by/ $4.0 /)$.

\begin{abstract}
The study posed a research question: did the situation caused by COVID-19 affect the economic position of energy companies? The aim of the study is to investigate the impact of the situation of the epidemic state introduced in 2020 on the activities of the efficiency of energy sector companies. The subject of the research will be the ten largest Polish power plants in terms of electricity production, including four capital groups to which they belong. Financial data from 2014 to 2020 will be used for the research. To test the effectiveness, the tools of the ratio analysis will be used. The analysis of the financial statements in terms of investments in manufacturing activities confirms the hypothesis that companies investing in new solutions and technologies will be best prepared for an exceptional situation. The results of the research show that those capital groups which in the period preceding the outbreak of the epidemic made the largest investment outlays and at the same time their financial ratios and market valuation on the Warsaw Stock Exchange were the highest, they also achieved the highest financial results during the pandemic - they had the most favorable economic situation.
\end{abstract}

Keywords: energy; energy company; efficiency; financial analysis; pandemic

\section{Introduction}

The impact of the COVID-19 pandemic on the economic and social situation in Poland [1-5], other European Union countries [6-8], and the world is unquestionable and multifaceted.

The occurrence of the COVID-19 pandemic and the economic and social restrictions caused by it has had a huge impact not only on the economies of individual countries but also on the financial situation of households and entrepreneurs. [9] The economic consequences of the COVID-19 pandemic and its impact on the global economy and the financial crisis of consumers and businesses have been analyzed by commercial research institutes and academic centers around the world: Teresiene [10], van der Wielen, and Barrios [11], Baker [9], Kanapickiene [12].

A significant decrease was observed in production and borrowing caused by COVID19 [13], a negative impact on the performance of companies in many sectors of the economy [14]. The most significant losses were recorded in the following industries: airlines, automobiles, hotel facilities or restaurants [15]; many experienced a reduction in wages for work or were put out of work [16]. The negative impact of COVID-19 cases has been noted on the change in investor sentiment [17], pessimism, and risk aversion among investors, on the value of the stock market [9], Al-Awadhi [18], increasing the volatility of these markets Ashraf [19], and stock returns and thus on financial markets around the 
world [20], resulting in higher levels of stock market volatility, and negative impact on the stock market [18,21-23].

All over the world, solutions are still being sought to mitigate the sudden economic shock, to keep the primary sectors of the economies of individual countries [24] functioning in the face of rising social expectations [25].

At the EU level and in individual countries, it has forced the need for governmental, institutional, and individual actions to counter its financial, organizational, and social implications, address the underlying economic risks associated with the pandemic, and increase the resilience of economies [26-30]. Domestic restrictions and restriction of movement (lockdown) have had effects in many areas of life: a global recession, increased debt and reduced economic potential disparities [31], and accelerated digital economy development, including the services market [32]. The crisis caused by COVID-19 threatens global financial stability due to uncertainty about its sustainability and intensity, affects financial problems, corporate failures, and unemployment in the long term, asset prices that have fallen dramatically, market liquidity a decline in investor confidence [18,33,34].

It also generated the need to identify current research directions developed around COVID-19 and its impact on the business environment in different sectors of the economy [35-38].

In the first quarter of 2020, a slight price decrease was noticed on the European electricity and coal market [39,40]. The COVID-19 pandemic created uncertainty about the future of the national and world economies and introduced uncertainty about its course, including the implications for demand variability [41-44]. The economic downturn and constraints imposed by national authorities have caused a temporary fall in electricity demand by businesses (industry), while school closures and remote working have increased its consumption by households [45-50]. The pandemic highlighted the importance of energy in the social order through closures, disruptions in mobility, and the shift to digital modes of remote working. It also meant that action had to be taken, including at the EU level $[27,28,30,51]$, to ensure the continued operation of the European energy system during the pandemic. It has created specific risks for the sector, and it has become critical to sustaining the security of supply to manage it effectively in the face of key risks (reduced demand for electricity, moratoriums on construction projects, reduced staff availability, and travel restrictions affecting access to and maintenance of operational assets) [52]. COVID19 also impacted stakeholders in the power sector-shareholders, stockholders, lenders, insurers, brokers, and others. They analyze the impact of the pandemic on balance sheets and the overall risk landscape, including climate change and environmental and social governance (ESG) issues and the transformation of the risk landscape in the energy industry, which, beyond COVID-19, is becoming the most important business driver, not just for the energy industry [53].

On one side, the energy market consists of the production, transmission, distribution, and trade of fuels and energy, and on the other side, the energy recipients affect the shaping of the environment. It influences landscape changes caused by opencast coal mining, construction of hydroelectric power plants, or the generation of smog caused by excessive exhaust fumes in a specific area. It also directly impacts the entire economy, including product prices, wages, returns on investment, and even the direction of development. Its strong connection to the rest of the economy makes countries focus on energy security to protect their interests [54]. The energy policy of Poland, consistent with the European Union's policy, considers the climate and energy objectives to counteract climate change. Its assurance would not be possible without the ability of the power system to ensure the security of operation of the power grid and balance the supply of electricity with the demand for this energy [55]. However, the implementation of changes in the energy structure is not possible without financial outlays.

While extensive research has been carried out to show the impact of COVID-19 on the economy, the situation, and the financial standing of entrepreneurs in various countries from different industries, the impact of the pandemic on the energy sector in Poland has 
not been studied. For these reasons, it seemed appropriate to investigate and answer whether the emergency caused by COVID-19 affected the economic crisis of the largest listed energy companies operating in Poland. The aim of the research is to show that those capital groups which in the period preceding the outbreak of the epidemic made the largest investment outlays and at the same time their financial ratios and market valuation on the Warsaw Stock Exchange were the highest, also during the pandemic, they achieved the highest financial results - they had the most favorable economic situation. The authors hypothesized that companies investing in new solutions and technologies are best prepared for an exceptional situation.

\section{Materials and Methods}

The answer to the research question posed in the introduction will help to examine the impact that the epidemic state introduced in 2020 has had on the efficiency of companies in the energy sector.

The subject of the study was the financial data of the ten most significant in terms of electricity production Polish utility power plants belonging to four capital groups. The economic data of the capital groups, parent companies, and the electricity generation segment of the capital groups whose shares are listed on the stock exchange were analyzed. Financial data from consolidated financial statements of capital groups, financial data from individual financial statements of parent companies, and management reports on the companies' activities were used to determine the financial position of power generation companies. The study period covers the years 2014-2020.

The capital groups selected for the study are: Polska Grupa Energetyczna (PGE), Tauron, Enea and Zespół Elektrowni Pątnów-Adamów-Konin (ZE PAK). These capital groups are the largest electricity producers in Poland, as they own at least one of the ten largest power plants in Poland. The capital groups are vertically integrated companies, present in the entire energy value chain-from extraction through generation in conventional and renewable energy sources to the distribution and sale of electricity. The entities accepted for the study are involved in the following subsectors: generation, transmission, distribution, and sales of energy in the wholesale and retail market segments. The entities of the energy sector are presented in Figure 1. 


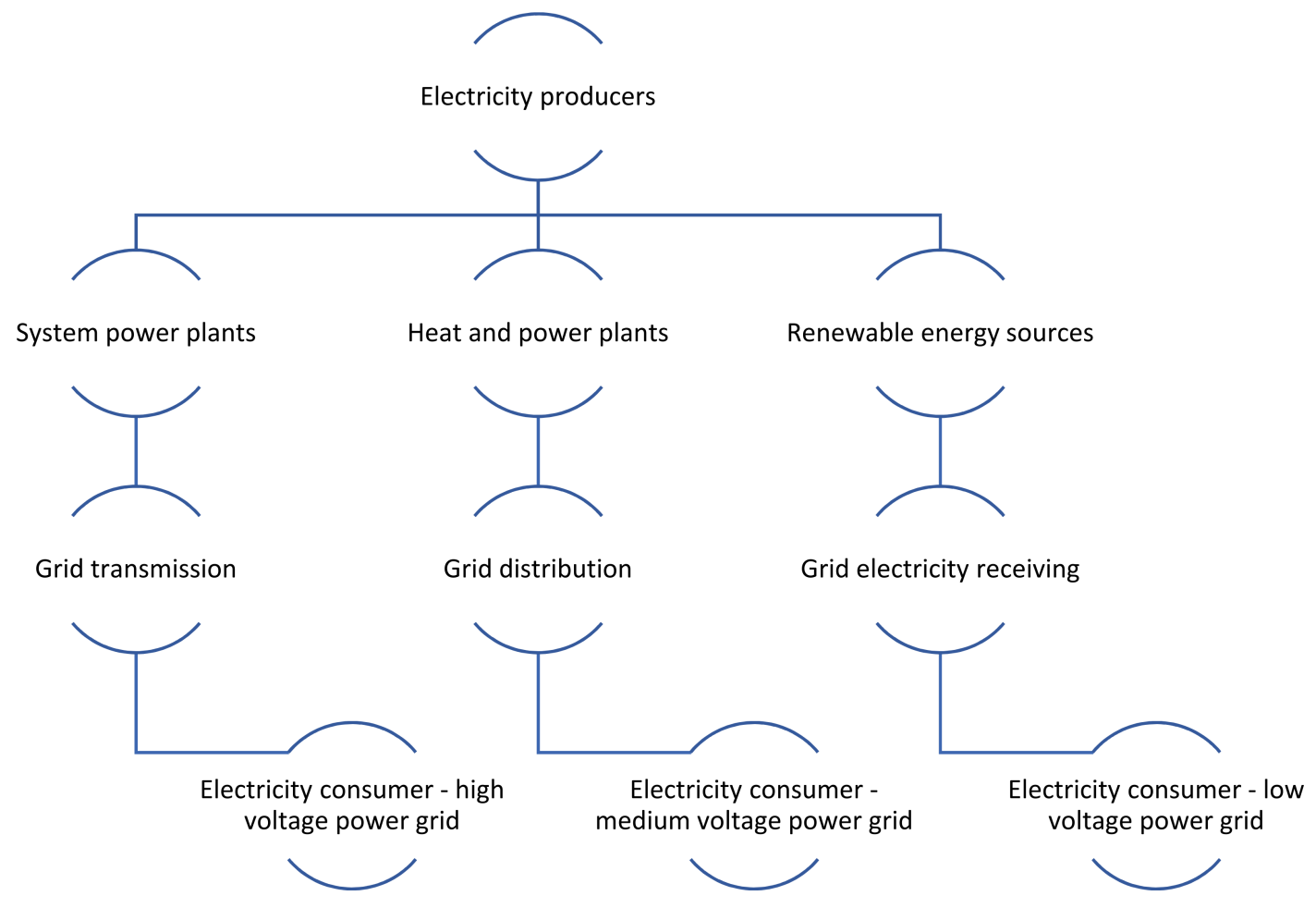

Figure 1. The energy sector in Poland.

In order to examine the effectiveness, the authors used ratio analysis tools were used, i.e., financial ratios, liquidity, debt, profitability, and efficiency.

The method of examining the efficiency of energy companies of the sector was divided into two parts. In the first part, ratio analysis of four capital groups, four parent companies, and selected indicators of the generation segment of each capital group was carried out. In particular, the data made available in the operating segment notes of the consolidated financial statements were examined. In situations where groups do not provide information necessary to calculate a given ratio, the data is determined based on the group's consolidated financial statements or estimated, e.g., information on the equity of the generation segment. In the next step of the research, the expenses, EBIT (Earning Before Interest and Taxes), and EBITDA of examined components are analyzed. The elimination of the cost of external capital will allow for a more accurate assessment of the operating efficiency of the segments. Due to the lack of studies in the literature on the impact of the ongoing situation on energy companies, an analysis will be carried out of the type and size of investments made in manufacturing operations and share price trends of parent companies, which will allow confirming the hypothesis that companies investing in new solutions and technologies will be best prepared for the emergency, will be the most effective. To confirm the hypothesis, it is necessary to achieve the aim of the study.

\section{Results}

\subsection{Analysis of Equity Financial Data of Energy Groups}

The analysis of financial data of the largest energy producers was preceded by a study of the electricity market situation. The research shows that in Poland, from 2014 to 2018 there was a systematic increase in electricity consumption and a decrease in consumption was marked in 2019 by $0.9 \%$ and by $2.3 \%$ in 2020 . On the other hand, a decrease in electricity production occurred in the last three years studied, in 2018 by $0.38 \%$, in 2019 by $3.9 \%$ and in 2020 by $4.1 \%$ compared to the previous year. On the other hand, the installed capacity in the national electricity system has been steadily increasing. In the last three years, the level of installed capacity increased by respectively: $5.8 \%, 1.9 \%, 5.2 \%$ [56]. 
The implementation of the main goal of the research required the determination of the financial situation of capital groups. The analysis of the Polish Energy Group's financial data for 2014-2019 indicates that the group's balance sheet total increased by PLN 11.449 billion, i.e., by $17 \%$, and only in 2020 by another PLN 3.844 billion, i.e., in the entire period under review it increased by $22 \%$. The level of the group's equity fluctuated during the period under review, decreasing by 3\% by 2019 and increasing by 1\% in 2020 (Table 1).

Table 1. Changes in total assets and equity of the PGE Capital Group from 2014 to 2020 (in PLN millions).

\begin{tabular}{lcccc}
\hline Year & $\begin{array}{c}\text { Balance Sheet } \\
\text { Total }\end{array}$ & Dynamics & Equity & Dynamics \\
\hline 2014 & 66,201 & Not applicable & 44,884 & Not applicable \\
2015 & 61,296 & $-7 \%$ & 40,417 & $-10 \%$ \\
2016 & 67,474 & $10 \%$ & 42,775 & $6 \%$ \\
2017 & 72,106 & $7 \%$ & 46,353 & $8 \%$ \\
2018 & 75,905 & $5 \%$ & 47,801 & $3 \%$ \\
2019 & 77,650 & $2 \%$ & 43,137 & $-10 \%$ \\
Change & 11,449 & $17 \%$ & -1747 & $-3 \%$ \\
2020 & 81,594 & $5 \%$ & 43,501 & $1 \%$ \\
Change & 15,293 & $22 \%$ & -1383 & $-2 \%$ \\
\hline
\end{tabular}

Own study based on the annual consolidated financial statements of the capital group PGE for the years 2014-2020.

Based on the data obtained, it can be concluded that the group's business is constantly growing. The increase in the balance sheet total, along with the rise in equity and the decrease in the share of equity between 2014 and 2018, shows that the percentage of the company's liabilities has increased. Thus the company has been investing, which is confirmed by the number of investment expenditures made in the sector under study presented later in this paper.

Table 2 summarizes the net profits, net sales revenues, and tangible fixed assets of the group. During the period in question, investments were made in fixed assets. The item of tangible fixed assets increased by 12.003 billion PLN, which increased their value in the whole period in question by $23 \%$.

Table 2. Net profit, revenues and tangible fixed assets of the PGE Capital Group (in PLN million) for 2014-2020.

\begin{tabular}{|c|c|c|c|c|c|}
\hline Year & Net Profit & Revenues & Dynamics & $\begin{array}{c}\text { Tangible } \\
\text { Fixed } \\
\text { Assets }\end{array}$ & Dynamics \\
\hline 2014 & 3657 & 28,137 & Not applicable & 49,738 & Not applicable \\
\hline 2015 & -3037 & 28,542 & $1 \%$ & 47,068 & $-5 \%$ \\
\hline 2016 & 2566 & 28,092 & $-2 \%$ & 51,365 & $9 \%$ \\
\hline 2017 & 2667 & 23,100 & $-18 \%$ & 58,620 & $14 \%$ \\
\hline 2018 & 1511 & 25,946 & $12 \%$ & 62,274 & $6 \%$ \\
\hline 2019 & -3928 & 37,627 & $45 \%$ & 59,690 & $-4 \%$ \\
\hline Change & Not applicable & 9490 & $41 \%$ & 9952 & $20 \%$ \\
\hline 2020 & 148 & 45,766 & $22 \%$ & 61,741 & $3 \%$ \\
\hline Change & Not applicable & 17,629 & $63 \%$ & 12,003 & $23 \%$ \\
\hline
\end{tabular}

In two years, i.e., 2015 and 2019, the PGE group recorded net losses due to increased cost of sales, in which it recognized impairment losses on fixed assets. By 2019, the PGE Group increased fixed assets by $20 \%$ and revenues by $41 \%$, while revenues increased by another $22 \%$ in 2020 alone (Table 2).

In 2019, the PGE Group recognized impairment losses on financial and non-financial assets of the examined segments for PLN 8.347 billion. It reversed impairment losses on assets recognized in previous reporting periods in the Renewable Energy segment for 
PLN 394 million. As a result of the impairment tests performed, the group recognized the creation and reversal of impairment losses on all non-current assets for PLN 7129 million under Depreciation and impairment losses. In total, the creation and reversal of writedowns for PLN 7518 million was recognized throughout 2019.

Table 3 shows the percentage of volumes characterizing the group's segments under study.

Table 3. Percentage share of conventional power generation and renewable power generation by line item in PGE's consolidated financial statements from 2014 to 2020.

\begin{tabular}{lccccc}
\hline Year & Revenues & Cost of Sales & Assets & Receivables & Liabilities \\
\hline 2014 & $48 \%$ & $65 \%$ & $59 \%$ & $23 \%$ & $41 \%$ \\
2015 & $47 \%$ & $61 \%$ & $60 \%$ & $21 \%$ & $47 \%$ \\
2016 & $44 \%$ & $44 \%$ & $58 \%$ & $22 \%$ & $36 \%$ \\
2017 & $60 \%$ & $63 \%$ & $64 \%$ & $50 \%$ & $36 \%$ \\
2018 & $67 \%$ & $73 \%$ & $66 \%$ & $49 \%$ & $40 \%$ \\
2019 & $70 \%$ & $78 \%$ & $55 \%$ & $33 \%$ & $49 \%$ \\
2020 & $68 \%$ & $64 \%$ & $60 \%$ & $43 \%$ & $51 \%$ \\
Average & $58 \%$ & $64 \%$ & $60 \%$ & $33 \%$ & $43 \%$ \\
\hline
\end{tabular}

Own study based on the annual consolidated financial statements of the capital group PGE for the years 2014-2020.

The consolidated result of the PGE Group comprises the financial results of its individual operating segments. Between 2014 and 2020, the conventional and renewable energy segments held an average share of $58 \%$ in revenues, $64 \%$ in assets, and $43 \%$ in liabilities. The most significant change occurred in revenues and receivables, which increased their shares by ten percentage points. The Conventional Power Generation segment has the largest share in the group's result, together with the Renewable Energy segment accounting on average for almost $60 \%$ of annual EBITDA in the period under review [57].

The financial ratios calculated for PGE are presented in Table 4. 
Table 4. Financial ratios of the PGE Capital Group in 2014-2020.

\begin{tabular}{|c|c|c|c|c|c|c|c|}
\hline Liquidity Ratios & 2014 & 2015 & 2016 & 2017 & 2018 & 2019 & 2020 \\
\hline First coverage rate & 0.86 & 0.82 & 0.79 & 0.74 & 0.72 & 0.66 & 0.65 \\
\hline Second coverage rate & 1.13 & 1.08 & 1.11 & 1.01 & 0.95 & 1.01 & 1 \\
\hline Current ratio & 1.93 & 1.54 & 1.74 & 1.06 & 0.73 & 1.06 & 1 \\
\hline Quick ratio & 1.63 & 1.29 & 1.53 & 0.85 & 0.51 & 0.68 & 0.8 \\
\hline Working capital share in assets & 0.1 & 0.07 & 0.08 & 0.01 & -0.04 & 0.01 & 0.0008 \\
\hline Debt ratios & 2014 & 2015 & 2016 & 2017 & 2018 & 2019 & 2020 \\
\hline Debt ratio & $32.20 \%$ & $34.06 \%$ & $36.61 \%$ & $35.72 \%$ & $37.03 \%$ & $44.45 \%$ & $46.69 \%$ \\
\hline Equity ratio & $67.80 \%$ & $65.94 \%$ & $63.39 \%$ & $64.28 \%$ & $62.97 \%$ & $55.55 \%$ & $53.31 \%$ \\
\hline Debt-to-equity ratio & $47.49 \%$ & $51.66 \%$ & $57.74 \%$ & $55.56 \%$ & $58.79 \%$ & $80.01 \%$ & $87.57 \%$ \\
\hline Long-term debt ratio & $31.31 \%$ & $32.89 \%$ & $39.75 \%$ & $36.19 \%$ & $32.59 \%$ & $52.59 \%$ & $53.04 \%$ \\
\hline Fixed assets debt ratio & $353.98 \%$ & $354.03 \%$ & $302.11 \%$ & $349.49 \%$ & $399.76 \%$ & $263.10 \%$ & $267.57 \%$ \\
\hline Overall financial condition ratio & 0.57 & 0.46 & 0.43 & 0.27 & 0.23 & 0.24 & 0.26 \\
\hline Activity ratios & 2014 & 2015 & 2016 & 2017 & 2018 & 2019 & 2020 \\
\hline Asset turnover ratio & 0.43 & 0.47 & 0.42 & 0.32 & 0.34 & 0.48 & 0.56 \\
\hline Inventory turnover ratio & 12.94 & 14.57 & 17.6 & 12.29 & 9.61 & 8.34 & 14.65 \\
\hline Inventory turnover ratio in days & 28.21 & 25.05 & 20.74 & 29.69 & 37.97 & 43.74 & 24.91 \\
\hline Receivable turnover ratio & 16.28 & 7.62 & 4.44 & 6.56 & 6.33 & 7.81 & 9.51 \\
\hline Receivable turnover ratio in days & 22.42 & 47.93 & 82.18 & 55.65 & 57.71 & 46.71 & 38.38 \\
\hline Liabilities turnover ratio & 23.87 & 7.23 & 7.9 & 7.15 & 7.18 & 10.35 & 13.06 \\
\hline Liabilities turnover ratio in days & 15.29 & 50.45 & 46.2 & 51.05 & 50.83 & 35.27 & 27.95 \\
\hline Cash conversion cycle & 35.34 & 22.53 & 56.71 & 34.29 & 44.85 & 55.18 & 35.34 \\
\hline Profitability ratios & 2014 & 2015 & 2016 & 2017 & 2018 & 2019 & 2020 \\
\hline EBITDA profitability ratio & $28.85 \%$ & $28.83 \%$ & $26.26 \%$ & $33.12 \%$ & $24.57 \%$ & $-11.10 \%$ & $3.08 \%$ \\
\hline Return On Assets & $5.52 \%$ & $-4.95 \%$ & $3.80 \%$ & $3.70 \%$ & $1.99 \%$ & $-5.06 \%$ & $0.18 \%$ \\
\hline Return On Equity & $8.15 \%$ & $-7.51 \%$ & $6.00 \%$ & $5.75 \%$ & $3.16 \%$ & $-9.11 \%$ & $0.34 \%$ \\
\hline Net profit margin & $12.99 \%$ & $-10.64 \%$ & $9.13 \%$ & $11.55 \%$ & $5.82 \%$ & $-10.44 \%$ & $0.32 \%$ \\
\hline Gross profit margin & $16.39 \%$ & $-13.16 \%$ & $11.65 \%$ & $14.24 \%$ & $8.45 \%$ & $-12.50 \%$ & $0.69 \%$ \\
\hline Gross profit margin on sales & $22.77 \%$ & $-5.34 \%$ & $17.51 \%$ & $23.74 \%$ & $18.89 \%$ & $-6.66 \%$ & $9.08 \%$ \\
\hline
\end{tabular}

Own study based on the annual consolidated financial statements of the capital group PGE for the years 2014-2020.

The liquidity measurement during the period under review shows a deteriorating financial position, but not a bad one. The debt level of the group is increasing. The efficiency ratios reach very different stories. The cash cycle took its lowest level in 2019. Of particular note in Table 4 are the profitability ratios for 2015, which resemble a negative value. In 2015 , the group raised its operating loss. This happened because the group wrote down the value of manufacturing assets to PLN 9.029 billion, wherein in other years, similar writedowns were for significantly lower amounts. Profitability ratios are decreasing from year to year. The lack of profitability is marked in 2015 and 2019. In summary, the year-on-year decline in profitability ratios, the financial liquidity ratios, and the increase in the share of short-term debt suggest that the company's financial position group deteriorated in the period under review.

The Tauron capital group's financial data analysis from 2014 to 2020 allows us to conclude that the group increased its assets by $15 \%$. The balance sheet total was raised by PLN 4.852 billion (Table 5). 
Table 5. Changes in the balance sheet total and equity of Tauron Capital Group in the years 2014-2020 (in PLN million).

\begin{tabular}{lcccc}
\hline Year & Balance Total & Dynamics & Total Equity & Dynamics \\
\hline 2014 & 34,559 & Not applicable & 17,997 & Not applicable \\
2015 & 32,071 & $-7 \%$ & 16,018 & $-11 \%$ \\
2016 & 33,457 & $4 \%$ & 16,679 & $4 \%$ \\
2017 & 35,792 & $7 \%$ & 18,068 & $8 \%$ \\
2018 & 37,097 & $4 \%$ & 18,429 & $2 \%$ \\
2019 & 41,918 & $13 \%$ & 19,093 & $4 \%$ \\
Change & 7359 & $21 \%$ & 1096 & $7 \%$ \\
2020 & 39,411 & $-6 \%$ & 16,412 & -14 \\
Change & 4852 & $-15 \%$ & -1585 & $-7 \%$ \\
\hline
\end{tabular}

Own study based on the annual consolidated financial statements of the capital group Tauron for the years 2014-2020.

By 2019 , as the balance sheet total increased, equity also increased by $2 \%$, resulting in a nominal increase of PLN 1.096 billion. This means that the group incurred additional liabilities during the period under review allocated to investments, highlighting a $12 \%$ increase in property, plant, and equipment by 2019 and another $11 \%$ in 2020 .

Table 6 summarizes the group's net earnings, net sales revenues, and tangible fixed assets.

Table 6. Net profit, revenues and tangible fixed assets of Tauron Capital Group in 2014-2020 (in PLN million).

\begin{tabular}{lccccc}
\hline Year & Net Profit & Revenues & Dynamics & $\begin{array}{c}\text { Tangible } \\
\text { Fixed Assets }\end{array}$ & Liabilities \\
\hline 2014 & 1185 & 18,440 & Not applicable & 24,850 & Not applicable \\
2015 & -1804 & 18,375 & $0 \%$ & 24,882 & $0 \%$ \\
2016 & 370 & 17,646 & $-4 \%$ & 26,355 & $6 \%$ \\
2017 & 1382 & 17,416 & $-1 \%$ & 28,079 & $7 \%$ \\
2018 & 207 & 18,121 & $4 \%$ & 29,238 & $4 \%$ \\
2019 & -12 & 20,065 & $11 \%$ & 27,927 & $-4 \%$ \\
Change & Not applicable & 1625 & $9 \%$ & 3077 & $12 \%$ \\
2020 & -2488 & 20,434 & $2 \%$ & 31,099 & $11 \%$ \\
Change & Not applicable & 1994 & $11 \%$ & 6249 & $25 \%$ \\
\hline
\end{tabular}

Own study based on the annual consolidated financial statements of the capital group Tauron for the years 2014-2020.

The group recorded a net loss in 2015, 2019, and 2020. In 2015, this was due to impairment charges of PLN 3.6 billion (compared to PLN 0.52 billion in 2014). In the remaining years, the group achieved positive financial results. The increase in the cost of impairment losses on tangible fixed assets, and goodwill concerned the Generation segment.

In the year ending 31 December 2016, the group, after taking into account the following premises, prolonged persistence of the market value of net assets below the carrying amount, decreased the prices of renewable energy certificates of origin, introduced new regulations in the area of renewable energy, saw persistent unfavorable market conditions from the point of view of the profitability of the coal power industry, increased the riskfree rate, recognized impairment losses and reversed previously created write-downs of property, tangible fixed assets resulting from asset impairment tests. As a result of the tests, some of the assets of the Generation Segment were subject to additional write-downs for PLN 1942.9 million. The impairment tests also proved the reversal of impairment allowances in this segment for PLN 1208.2 million. The total impact of write-downs on the group's 2016 pre-tax profit amounted to PLN 0.787 billion (excess of creation over reversal).

In 2019, impairment losses on property, tangible fixed assets impacted the segment, resulting in the amount of PLN 0.635 billion (increase in write-downs for PLN 0.694 and decrease in the amount of PLN 0.059 billion). In 2020, the total impact on the result of the period was PLN 2.618 billion (an increase of write-offs for PLN 2.622 billion). 
The increase in fixed assets did not result in a proportional increase in revenue. The group recorded an $11 \%$ increase in revenue over the entire period under review, including an $11 \%$ increase in 2019 alone (Table 6).

Table 7 shows the share of the conventional and renewable energy segment in the group's entire business. This share is significantly lower than in the case of the Polish Energy Group due to significant differences in the level of generation capacity and the classification of liabilities; in the case of the Tauron Group, most liabilities were not assigned to any of the activities.

Table 7. Percentage share of conventional and renewable energy in individual items of Tauron group's consolidated financial statements, 2014-2020.

\begin{tabular}{lcccc}
\hline Year & Revenues & Cost of Sales & Assets & Liabilities \\
\hline 2014 & $27 \%$ & $32 \%$ & $38 \%$ & $10 \%$ \\
2015 & $29 \%$ & $47 \%$ & $34 \%$ & $11 \%$ \\
2016 & $25 \%$ & $33 \%$ & $33 \%$ & $12 \%$ \\
2017 & $26 \%$ & $31 \%$ & $33 \%$ & $10 \%$ \\
2018 & $26 \%$ & $27 \%$ & $34 \%$ & $7 \%$ \\
2019 & $21 \%$ & $24 \%$ & $36 \%$ & $10 \%$ \\
2020 & $22 \%$ & $36 \%$ & $31 \%$ & $11 \%$ \\
Average & $25 \%$ & $33 \%$ & $31 \%$ & $10 \%$ \\
\hline
\end{tabular}

Own study based on the annual consolidated financial statements of the capital group Tauron for the years 2014-2020.

The share of the generation segment for the Tauron group is virtually unchanged and did not change significantly in the period under review. In 2015, the share of assets fell from $38 \%$ to $34 \%$ due to the impairment charge, in the same year the segment also recorded the highest share in own costs at $47 \%$. In 2020, the results obtained confirm the occurrence of a similar situation to that of 2015.

Table 8 presents selected financial indicators for the Tauron Group's generation business.

Table 8. Financial ratios of Tauron capital group in the years 2014-2020.

\begin{tabular}{|c|c|c|c|c|c|c|c|}
\hline Liquidity Ratios & 2014 & 2015 & 2016 & 2017 & 2018 & 2019 & 2020 \\
\hline First coverage rate & 0.64 & 0.57 & 0.57 & 0.58 & 0.57 & 0.54 & 0.52 \\
\hline Second coverage rate & 1.06 & 0.88 & 0.98 & 0.99 & 0.92 & 0.97 & 1.01 \\
\hline Current ratio & 1.33 & 0.53 & 0.9 & 0.95 & 0.63 & 0.87 & 1.05 \\
\hline Quick ratio & 1.22 & 0.47 & 0.79 & 0.89 & 0.56 & 0.79 & 0.94 \\
\hline Working capital share in assets & 0.05 & -0.11 & -0.01 & -0.01 & -0.07 & -0.02 & 0.01 \\
\hline Debt ratios & 2014 & 2015 & 2016 & 2017 & 2018 & 2019 & 2020 \\
\hline Debt ratio & $47.93 \%$ & $49.96 \%$ & $50.15 \%$ & $49.52 \%$ & $50.32 \%$ & $54.45 \%$ & $58.36 \%$ \\
\hline Equity ratio & $52.07 \%$ & $50.04 \%$ & $49.85 \%$ & $50.48 \%$ & $49.68 \%$ & $45.55 \%$ & $41.64 \%$ \\
\hline Debt-to-equity ratio & $92.03 \%$ & $99.84 \%$ & $100.59 \%$ & $98.10 \%$ & $101.31 \%$ & $119.55 \%$ & $140.13 \%$ \\
\hline Long-term debt ratio & $65.26 \%$ & $53.49 \%$ & $71.76 \%$ & $70.50 \%$ & $61.76 \%$ & $78.37 \%$ & $95.58 \%$ \\
\hline Fixed assets debt ratio & $211.60 \%$ & $289.88 \%$ & $220.20 \%$ & $220.44 \%$ & $256.87 \%$ & $207.84 \%$ & $178.02 \%$ \\
\hline Overall financial condition ratio & 0.25 & 0.14 & 0.15 & 0.16 & 0.14 & 0.16 & 0.17 \\
\hline Activity ratios & 2014 & 2015 & 2016 & 2017 & 2018 & 2019 & 2020 \\
\hline Asset turnover ratio & 0.54 & 0.57 & 0.53 & 0.49 & 0.49 & 0.47 & 0.52 \\
\hline Inventory turnover ratio & 35.21 & 42.41 & 36.3 & 58.97 & 35.55 & 28.59 & 26.21 \\
\hline Inventory turnover ratio in days & 10.37 & 8.61 & 10.05 & 6.19 & 10.27 & 12.77 & 13.93 \\
\hline Receivable turnover ratio & 9.69 & 10.04 & 9.32 & 8.57 & 8.13 & 8.54 & 8.62 \\
\hline Receivable turnover ratio in days & 37.67 & 36.35 & 39.18 & 42.58 & 44.9 & 42.75 & 42.35 \\
\hline Liabilities turnover ratio & 9.71 & 23.24 & 21.27 & 16.72 & 16.07 & 23.09 & 21.1 \\
\hline Liabilities turnover ratio in days & 37.59 & 15.71 & 17.16 & 21.84 & 22.71 & 15.81 & 17.3 \\
\hline Cash conversion cycle & 10.44 & 29.25 & 32.07 & 26.94 & 32.46 & 39.71 & 38.98 \\
\hline Profitability ratios & 2014 & 2015 & 2016 & 2017 & 2018 & 2019 & 2020 \\
\hline EBITDA profitability ratio & $19.52 \%$ & $-0.37 \%$ & $14.00 \%$ & $20.09 \%$ & $13.86 \%$ & $11.69 \%$ & $4.61 \%$ \\
\hline Return On Assets & $3.43 \%$ & $-5.63 \%$ & $1.11 \%$ & $3.86 \%$ & $0.56 \%$ & $-0.03 \%$ & $-6.31 \%$ \\
\hline Return On Equity & $6.59 \%$ & $-11.24 \%$ & $2.22 \%$ & $7.65 \%$ & $1.12 \%$ & $-0.06 \%$ & $-15.16 \%$ \\
\hline Net profit margin & $6.38 \%$ & $-9.82 \%$ & $2.10 \%$ & $7.94 \%$ & $1.14 \%$ & $-0.06 \%$ & $-12.21 \%$ \\
\hline Gross profit margin & $8.06 \%$ & $-11.91 \%$ & $2.88 \%$ & $10.09 \%$ & $2.78 \%$ & $-0.08 \%$ & $-8.13 \%$ \\
\hline Gross profit margin on sales & $15.76 \%$ & $-4.17 \%$ & $10.93 \%$ & $16.71 \%$ & $9.30 \%$ & $6.37 \%$ & $-1.30 \%$ \\
\hline
\end{tabular}


Based on the results obtained, it can be observed that the group's financial condition is weak from 2015 to 2019. During this period, the group shows a lack of liquidity. Depending on the year, the cash cycle ranges between 26 and 39 days, and the longest falls in 2019. The most extended period of credit to customers falls in 2018. The asset productivity ratios ranged between 0.47 and 0.57 , which is in a higher range than in the case of PGE. The profitability ratios take their lowest values in 2015, 2019, and 2020, i.e., the years with the highest asset impairment losses.

The deterioration of the group's financial position in the periods indicated was mainly influenced by impairment charges. Had these write-downs not occurred, the group would have shown positive values on each profitability ratio at a level similar to other periods. There are no significant concentrations of credit risk in the group related to its core business.

Financial data of the ENEA capital group, one of the largest distributors of electricity in Poland, which distinguishes the following business segments: extraction, generation, distribution, turnover, and other operations, is presented in Table 9 (balance sheet total and equity of the group, together with change dynamics).

Table 9. Balance sheet total and equity of the ENEA capital group in the years 2014-2020 (in PLN million).

\begin{tabular}{lcccc}
\hline Year & Balance Total & Dynamics & Total Equity & Dynamics \\
\hline 2014 & 18,108 & Not applicable & 12,064 & Not applicable \\
2015 & 22,988 & $27 \%$ & 12,123 & $0 \%$ \\
2016 & 24,536 & $7 \%$ & 13,011 & $7 \%$ \\
2017 & 28,312 & $15 \%$ & 14,000 & $8 \%$ \\
2018 & 29,965 & $6 \%$ & 15,049 & $7 \%$ \\
2019 & 32,844 & $10 \%$ & 15,480 & $3 \%$ \\
Change & 14,736 & $81 \%$ & 3416 & $28 \%$ \\
2020 & 29,890 & $-9 \%$ & 15,859 & $3 \%$ \\
Change & 11,782 & $65 \%$ & 3795 & $31 \%$ \\
\hline
\end{tabular}

Own study based on the annual consolidated financial statements of the capital group ENEA for the years 2014-2020.

In the surveyed years 2014-2020, the group increased the value of its assets by 65\%, increasing its balance sheet total by almost PLN 11.8 billion. This is the most significant change in nominal terms and by far the largest among the surveyed groups. Taking into account the percentage increase far surpasses the companies surveyed to date. Equity in the analyzed years increased by PLN 3.795 billion, which results in a rise of $31 \%$ in the entire period studied, including $28 \%$ until 2019. This shows that external financing mainly contributed to the increase in total assets.

Table 10 shows net income, tangible fixed assets from 2014 to 2020 . The increase in the balance sheet total was significantly affected by investments in property, plant, and equipment, which increased by 57\% until 2019 and decreased by only 1\% in 2020 .

Along with an increase in tangible fixed assets, the group's revenue increased by $85 \%$ during the period under review. Of the companies studied so far, only in the case of the ENEA group, there is a correlation between the growth of tangible fixed assets, and revenues. In 2015 and 2020 recorded a financial loss related to a write-down, which in the first case amounted to PLN 1.5 billion. In the remaining years, there were write-downs, but their value did not significantly impact the financial result.

The percentage share of revenues, costs, assets, and liabilities in the total values of the group is presented in Table 11. To determine the value of the segment's assets, information on the value of the segment's property, plant and equipment and the share of the group's property, plant and equipment in its assets was used. 
Table 10. Net profit, revenues and property, Tangible fixed assets of ENEA Capital Group in 2014-2020 (in PLN million).

\begin{tabular}{lccccc}
\hline Year & Net Profit & Revenues & Dynamics & $\begin{array}{c}\text { Tangible } \\
\text { Fixed Assets }\end{array}$ & Liabilities \\
\hline 2014 & 909 & 9855 & Not & 13,702 & $\begin{array}{c}\text { Not } \\
\text { capplicable } \\
2015\end{array}$ \\
2016 & -399 & 9848 & 0 capplicable & 17,075 & $25 \%$ \\
2017 & 849 & 11,256 & $14 \%$ & 18,382 & $8 \%$ \\
2018 & 1165 & 11,406 & $1 \%$ & 20,417 & $11 \%$ \\
2019 & 719 & 12,673 & $11 \%$ & 21,027 & $3 \%$ \\
Change & 541 & 15,796 & $25 \%$ & 21,471 & $2 \%$ \\
2020 & Not applicable & 5941 & $60 \%$ & 21,404 & $57 \%$ \\
Change & -2234 & 18,195 & $15 \%$ & 7702 & $-1 \%$ \\
\hline
\end{tabular}

Own study based on the annual consolidated financial statements of the capital group ENEA for the years 2014-2020.

Table 11. Percentage share of the generation segment in particular items of the consolidated financial statements of the ENEA Group in the years 2014-2020.

\begin{tabular}{lcccc}
\hline Year & Revenues & Cost of Sales & Assets & Liabilities \\
\hline 2014 & $35 \%$ & $32 \%$ & $48 \%$ & $7 \%$ \\
2015 & $36 \%$ & $45 \%$ & $40 \%$ & $4 \%$ \\
2016 & $29 \%$ & $31 \%$ & $43 \%$ & $3 \%$ \\
2017 & $40 \%$ & $42 \%$ & $46 \%$ & $7 \%$ \\
2018 & $57 \%$ & $58 \%$ & $45 \%$ & $6 \%$ \\
2019 & $51 \%$ & $48 \%$ & $44 \%$ & $5 \%$ \\
2020 & $46 \%$ & $66 \%$ & $32 \%$ & $4 \%$ \\
Average & $42 \%$ & $46 \%$ & $35 \%$ & $5 \%$ \\
\hline
\end{tabular}

Own study based on the annual consolidated financial statements of the capital group ENEA for the years 2014-2020.

The most significant change in the generation sector occurred in the revenue item, which increased from $29 \%$ to $57 \%$ in 2018 . The share of segment assets declined from $48 \%$ to $32 \%$ in 2020 due to a write-down of the segment's assets of PLN 1.5 billion. The group's total assets increased by $65 \%$. Thus, despite the decrease in the share of the segment's assets in the total assets of the group, in nominal terms, the value of the generation segment's assets increased from PLN 8.777bn to PLN 14.379bn in 2014-2019, to decrease by PLN 4.925bn in 2020. As in the case of the Tauron capital group, the ENEA group did not allocate the majority of its liabilities to any of the segments, which results in a low share of generation in the total amount of liabilities. Table 12 presents the financial ratios of the ENEA capital group.

Liquidity ratios were within the ranges defined in the literature, with a focus on over liquidity. We observed an increase in group debt and leverage. The rise in debt did not result in significant changes in the term debt ratio. During the study period, the cash turnover cycle decreased until 2018 to 2016 in 2019, influenced by a decrease in the receivables turnover ratio from 65 days to 44 days. From 2016 to 2018, there was an increase in the asset productivity ratio from 0.4 to 0.71 , the best among the companies studied. Profitability ratios were positive in all years except 2015 and 2020. In 2015, as was the case with the other companies, an impairment charge was made, which significantly affected the company's financial result (without the cost, the ratios would have reached a level similar to 2014). Based on the financial ratios, it can be concluded that the financial position of the group improved during the period under review. 
Table 12. Financial ratios of ENEA capital group in the years 2014-2020.

\begin{tabular}{|c|c|c|c|c|c|c|c|}
\hline Liquidity Ratios & 2014 & 2015 & 2016 & 2017 & 2018 & 2019 & 2020 \\
\hline First coverage rate & 0.84 & 0.67 & 0.67 & 0.63 & 0.65 & 0.65 & 0.6 \\
\hline Second coverage rate & 1.13 & 1.13 & 1.11 & 1.09 & 1.09 & 1.11 & 1.06 \\
\hline Current ratio & 2.03 & 1.99 & 1.73 & 1.47 & 1.44 & 1.39 & 1.2 \\
\hline Quick ratio & 1.76 & 1.72 & 1.58 & 1.27 & 1.18 & 1.18 & 1.03 \\
\hline Working capital share in assets & 0.11 & 0.1 & 0.09 & 0.07 & 0.07 & 0.08 & 0.04 \\
\hline Debt ratios & 2014 & 2015 & 2016 & 2017 & 2018 & 2019 & 2020 \\
\hline Debt ratio & $33.38 \%$ & $47.27 \%$ & $46.97 \%$ & $50.55 \%$ & $49.78 \%$ & $52.87 \%$ & $56.19 \%$ \\
\hline Equity ratio & $66.62 \%$ & $52.73 \%$ & $53.03 \%$ & $49.45 \%$ & $50.22 \%$ & $47.13 \%$ & $43.81 \%$ \\
\hline Debt-to-equity ratio & $50.10 \%$ & $89.64 \%$ & $88.57 \%$ & $102.24 \%$ & $99.12 \%$ & $112.17 \%$ & $128.27 \%$ \\
\hline Long-term debt ratio & $34.73 \%$ & $69.77 \%$ & $66.15 \%$ & $71.88 \%$ & $67.18 \%$ & $70.13 \%$ & $76.44 \%$ \\
\hline Fixed assets debt ratio & $325.00 \%$ & $201.88 \%$ & $213.58 \%$ & $202.89 \%$ & $207.99 \%$ & $197.79 \%$ & $188.86 \%$ \\
\hline Overall financial condition ratio & 0.52 & 0.29 & 0.29 & 0.28 & 0.30 & 0.34 & 1.07 \\
\hline Activity ratios & 2014 & 2015 & 2016 & 2017 & 2018 & 2019 & 2020 \\
\hline Asset turnover ratio & 0.56 & 0.44 & 0.47 & 0.41 & 0.43 & 0.48 & 0.61 \\
\hline Inventory turnover ratio & 19.79 & 15.52 & 25.65 & 13.78 & 10.22 & 11.53 & 16.14 \\
\hline Inventory turnover ratio in days & 18.44 & 23.52 & 14.23 & 26.49 & 35.72 & 31.66 & 22.61 \\
\hline Receivable turnover ratio & 5.64 & 5.72 & 6.21 & 6.03 & 6.81 & 7.4 & 8.27 \\
\hline Receivable turnover ratio in days & 64.77 & 63.76 & 58.81 & 60.54 & 53.59 & 49.33 & 44.11 \\
\hline Liabilities turnover ratio & 8.83 & 8.13 & 9.68 & 5.53 & 4.97 & 7.8 & 8.4 \\
\hline Liabilities turnover ratio in days & 41.33 & 44.89 & 37.73 & 66.01 & 73.48 & 46.77 & 43.43 \\
\hline Cash conversion cycle & 41.88 & 42.39 & 35.32 & 21.02 & 15.82 & 34.22 & 23.29 \\
\hline Profitability ratios & 2014 & 2015 & 2016 & 2017 & 2018 & 2019 & 2020 \\
\hline EBITDA profitability ratio & $19.43 \%$ & $6.38 \%$ & $19.81 \%$ & $23.52 \%$ & $19.84 \%$ & $21.55 \%$ & $-0.60 \%$ \\
\hline Return On Assets & $5.02 \%$ & $-1.74 \%$ & $3.46 \%$ & $4.11 \%$ & $2.40 \%$ & $1.65 \%$ & $-7.48 \%$ \\
\hline Return On Equity & $7.54 \%$ & $-3.29 \%$ & $6.52 \%$ & $8.32 \%$ & $4.78 \%$ & $3.49 \%$ & $-17.06 \%$ \\
\hline Net profit margin & $9.04 \%$ & $-3.96 \%$ & $7.37 \%$ & $9.99 \%$ & $5.56 \%$ & $3.41 \%$ & $-12.25 \%$ \\
\hline Gross profit margin & $11.37 \%$ & $-4.06 \%$ & $9.28 \%$ & $12.58 \%$ & $6.72 \%$ & $5.49 \%$ & $-14.27 \%$ \\
\hline Gross profit margin on sales & $12 \%$ & $15 \%$ & $12 \%$ & $14 \%$ & $7 \%$ & $7 \%$ & $9 \%$ \\
\hline
\end{tabular}

Own study based on the annual consolidated financial statements of the capital group ENEA for the years 2014-2020.

The analysis of the financial data of the capital group Zespół Elektrowni PątnówAdamów-Konin SA (ZE PAK) is presented in Tables 13-16. Table 13 shows the dynamics of changes in the balance sheet total and equity of the group.

Table 13. Balance sheet total and equity of the ZE PAK capital group in the years 2014-2020 (in PLN million).

\begin{tabular}{lcccc}
\hline Year & Balance Total & Dynamics & Total Equity & Dynamics \\
\hline 2014 & 6868 & Nie dotyczy & 3820 & Nie dotyczy \\
2015 & 4974 & $-28 \%$ & 1884 & $-51 \%$ \\
2016 & 4801 & $-3 \%$ & 2143 & $14 \%$ \\
2017 & 4455 & $-7 \%$ & 2264 & $6 \%$ \\
2018 & 3871 & $-13 \%$ & 1687 & $-25 \%$ \\
2019 & 3118 & $-19 \%$ & 1177 & $-30 \%$ \\
Change & -3750 & $-55 \%$ & -2643 & $-69 \%$ \\
2020 & 2879 & $-8 \%$ & 949 & $-19 \%$ \\
Change & -3989 & $-58 \%$ & -2133 & $-75 \%$ \\
\hline
\end{tabular}

Own study based on the annual consolidated financial statements of the capital group ZE PAK for the years 2014-2020. 
Table 14. Net profit, revenues and property, Tangible fixed assets of ZE PAK Capital Group in 2014-2020 (in PLN million).

\begin{tabular}{lccccc}
\hline Year & Net Profit & Revenues & Dynamics & $\begin{array}{c}\text { Tangible } \\
\text { Fixed Assets }\end{array}$ & Liabilities \\
\hline 2014 & 79 & 2680 & Not applicable & 5300 & Not applicable \\
2015 & -1880 & 2947 & $10 \%$ & 3475 & $-34 \%$ \\
2016 & 250 & 2705 & $-8 \%$ & 3391 & $-2 \%$ \\
2017 & 184 & 2443 & $-10 \%$ & 3280 & $-3 \%$ \\
2018 & -464 & 2305 & $-6 \%$ & 2791 & $-15 \%$ \\
2019 & -446 & 2878 & $25 \%$ & 1960 & $-30 \%$ \\
Change & Not applicable & 573 & $7 \%$ & -3340 & $-63 \%$ \\
2020 & -227 & 2207 & $-23 \%$ & 1661 & $-15 \%$ \\
Change & Not applicable & -671 & $-18 \%$ & -3639 & $-69 \%$ \\
\hline
\end{tabular}

Own study based on the annual consolidated financial statements of the capital group ZE PAK for the years 2014-2020.

Table 15. Percentage share of the generation segment in the individual items of the consolidated financial statements of the ZE PAK Group from 2014 to 2020.

\begin{tabular}{lccc}
\hline Year & Revenues & Cost of Sales & Financial Costs \\
\hline 2014 & $81 \%$ & $84 \%$ & $58 \%$ \\
2015 & $74 \%$ & $86 \%$ & $56 \%$ \\
2016 & $81 \%$ & $84 \%$ & $78 \%$ \\
2017 & $86 \%$ & $88 \%$ & $72 \%$ \\
2018 & $86 \%$ & $81 \%$ & $51 \%$ \\
2019 & $83 \%$ & $85 \%$ & $42 \%$ \\
2020 & $84 \%$ & $81 \%$ & $28 \%$ \\
Average & $82 \%$ & $84 \%$ & $55 \%$ \\
\hline
\end{tabular}

Own study based on the annual consolidated financial statements of the capital group ZE PAK for the years 2014-2020.

Table 16. Financial ratios of ZE PAK capital group in the years 2014-2020.

\begin{tabular}{|c|c|c|c|c|c|c|c|}
\hline Liquidity Ratios & 2014 & 2015 & 2016 & 2017 & 2018 & 2019 & 2020 \\
\hline First coverage rate & 0.67 & 0.51 & 0.58 & 0.66 & 0.57 & 0.54 & 0.51 \\
\hline Second coverage rate & 1 & 1 & 0.95 & 1 & 0.9 & 0.99 & 0.97 \\
\hline Current ratio & 0.68 & 0.7 & 0.87 & 1.01 & 0.75 & 0.98 & 0.96 \\
\hline Quick ratio & 0.49 & 0.57 & 0.78 & 0.91 & 0.66 & 0.87 & 0.89 \\
\hline Working capital share in assets & -0.06 & -0.08 & -0.04 & 0 & -0.08 & -0.01 & -0.02 \\
\hline Debt ratios & 2014 & 2015 & 2016 & 2017 & 2018 & 2019 & 2020 \\
\hline Debt ratio & $44.38 \%$ & $62.11 \%$ & $55.35 \%$ & $49.18 \%$ & $56.42 \%$ & $62.27 \%$ & $67.02 \%$ \\
\hline Equity ratio & $55.62 \%$ & $37.89 \%$ & $44.65 \%$ & $50.82 \%$ & $43.58 \%$ & $37.73 \%$ & $32.98 \%$ \\
\hline Debt-to-equity ratio & $79.80 \%$ & $163.92 \%$ & $123.98 \%$ & $96.78 \%$ & $129.46 \%$ & $165.05 \%$ & $203.18 \%$ \\
\hline Long-term debt ratio & $48.22 \%$ & $97.08 \%$ & $64.83 \%$ & $52.64 \%$ & $57.74 \%$ & $84.01 \%$ & $90.69 \%$ \\
\hline Fixed assets debt ratio & $287.73 \%$ & $189.93 \%$ & $244.02 \%$ & $275.25 \%$ & $286.52 \%$ & $198.31 \%$ & $192.86 \%$ \\
\hline Overall financial conditio ratio & 0.18 & 0.14 & 0.24 & 0.3 & 0.23 & 0.26 & 0.27 \\
\hline Activity ratios & 2014 & 2015 & 2016 & 2017 & 2018 & 2019 & 2020 \\
\hline Asset turnover ratio & 0.39 & 0.59 & 0.56 & 0.55 & 0.6 & 0.92 & 0.77 \\
\hline Inventory turnover ratio & 11.3 & 18.71 & 25.69 & 24.99 & 21.1 & 27.58 & 32.52 \\
\hline Inventory turnover ratio in days & 32.29 & 19.5 & 14.21 & 14.61 & 17.3 & 13.23 & 11.22 \\
\hline Receivable turnover ratio & 10.55 & 10.99 & 10.99 & 9.65 & 6.51 & 12.59 & 5.73 \\
\hline Receivable turnover ratio in days & 34.59 & 33.2 & 33.2 & 37.84 & 56.09 & 28.99 & 65.43 \\
\hline Liabilities turnover ratio & 25.83 & 36.51 & 533.58 & 474.75 & 200.98 & 24.44 & 11.41 \\
\hline Liabilities turnover ratio in days & 14.13 & 10 & 0.68 & 0.77 & 1.82 & 14.94 & 32 \\
\hline Cash conversion cycle & 52.75 & 42.7 & 46.73 & 51.67 & 71.57 & 27.29 & 44.65 \\
\hline Profitability ratios & 2014 & 2015 & 2016 & 2017 & 2018 & 2019 & 2020 \\
\hline EBITDA profitability ratio & $18.67 \%$ & $-48.00 \%$ & $21.42 \%$ & $19.88 \%$ & $-12.22 \%$ & $-8.35 \%$ & $-6.25 \%$ \\
\hline Return On Assets & $1.14 \%$ & $-37.79 \%$ & $5.21 \%$ & $4.12 \%$ & $-11.98 \%$ & $-14.31 \%$ & $-7.87 \%$ \\
\hline Return On Equity & $2.05 \%$ & $-99.73 \%$ & $11.68 \%$ & $8.11 \%$ & $-27.48 \%$ & $-37.92 \%$ & $-23.85 \%$ \\
\hline Net profit margin & $2.93 \%$ & $-63.77 \%$ & $9.25 \%$ & $7.51 \%$ & $-20.12 \%$ & $-15.50 \%$ & $-10.26 \%$ \\
\hline Gross profit margin & $3.66 \%$ & $-62.19 \%$ & $11.38 \%$ & $10.59 \%$ & $-22.36 \%$ & $-15.29 \%$ & $-13.73 \%$ \\
\hline Gross profit margin on sales & $8.51 \%$ & $-57.78 \%$ & $17.13 \%$ & $16.69 \%$ & $-14.02 \%$ & $-10.70 \%$ & $-10.88 \%$ \\
\hline
\end{tabular}


Between 2014 and 2020, total assets decreased by 58\% from PLN 6.87 billion to PLN 2.88 billion, including a $55 \%$ decrease by 2019 , In 2020, the value of assets decreased by $8 \%$ compared to 2019 . The highest declines in value occurred in 2015,2019 , and 2018 . In the period under review, equity decreased by 75\%, or by more than PLN 2.1 billion. The highest decrease in equity value occurred in 2015 and amounted to 51\%; the next one took place in 2019 at 30\%. However, in 2018 there was a noticeable decrease in the value of equity at $25 \%$.

As was the case with the other three groups, ZE PAK recorded a net loss in 2015 and 2020, when the group took asset write-downs. The first write-down amounted to nearly PLN 1.9 billion, resulting in a 51\% reduction in equity. In 2018 and the subsequent periods under review, the group also made total write-downs of much lower values (PLN 227, 603 , and 151 million, respectively). Table 14 summarizes the net financial results, revenue dynamics, and tangible fixed assets changes.

During the period under review, the group recorded losses four times. The highest in 2015 and consecutively in 2018, 2019, and 2020. However, if impairment losses were not taken into account, the group would have made a profit in 2015 and 2019, while in 2018 , it would have made about half the loss. The value of property, plant, and equipment decreased by 69\% over the entire period under review, the most in 2015 and 2019. On the other hand, the group's revenue declined by $18 \%$ over the whole period under review, the most in 2020, down 23\% from the previous year. The group did not make investments on the same scale as its competitors in the years under review.

The group does not have current assets, liabilities, and expenditures allocated to segments. The generation segment (four companies, including the parent company) generates the largest share of revenues and costs (Table 15).

Due to the lack of disclosures in the group's consolidated financial statements about the assets and liabilities separated into individual business segments, the data adopted for the analysis, in addition to revenue and own costs, relate to financial expenses. Between 2014 and 2020, the generation segment had an average share of $82 \%$ of the group's revenue, a share of $84 \%$ in 2020. Own costs averaged 84\% and were highest in 2015 and 2019. Finance costs averaged 55\%, falling from $78 \%$ in 2016 to $28 \%$ in 2020 . Segments other than generation account for a significantly smaller share of the group's business.

Table 16 shows the financial ratios calculated for the group.

The liquidity ratios of the group are at a superficial level (much lower than the optimal level indicated in the literature). During the period under review, the current liquidity increased from 0.68 to 0.98 , with the lowest level of the ratio occurring in 2014 . The quick liquidity ratio also performed below the minimum recommended threshold during the study period, with the highest level occurring in 2020. The general debt ratio was 0.44 in 2014 and was 0.67 at the end of 2020, which significantly affects the company's ability to incur future liabilities. The company enjoys high leverage, as evidenced by the debtto-equity ratio increasing from 0.8 to over two during the period under review, with a high proportion of long-term liabilities rising in 2019 and 2020. During the period under review, the cash cycle peaked in 2017 at over 77 days and was over 44 days in 2020. Asset productivity during the period under review increased from 0.39 in 2014 to 0.77 in 2020 . The group reached its highest productivity in 2019, with a ratio of 0.92 . This increase is related to creating a write-down of fixed assets, which still retain the ability to generate income, and by reducing their book value, the productivity of assets increases. The study of the group's profitability showed its absence in 2015 and 2018 to 2020, i.e., the years in which the group made write-downs or closed power plants. The group achieved the lowest level of net profit margin in 2015. 


\subsection{Evaluating the Financial Position of Capital Groups during the COVID-19 Pandemic-A} Summary of Results

The implementation of the research objective required a comparison of the financial situation of the surveyed capital groups. The following were compared: the scale of operation and investments made, profitability, and other indicators.

During the period under review, The Enea group recorded the most significant growth. The first six years under study increased its balance sheet total by $81 \%$ (Table 17). The reduction in the balance sheet total in 2020 resulted in a total increase in the value of assets in the period under the study of $65 \%$.

Table 17. Changes in the quantities studied between 2014 and 2020.

\begin{tabular}{|c|c|c|c|c|c|}
\hline Change (\%) & PGE & Tauron & ENEA & ZE PAK & Leader \\
\hline \multicolumn{6}{|c|}{ Until 2019} \\
\hline Total balance & 17 & 21 & 81 & -55 & ENEA \\
\hline Equity & -3 & 7 & 28 & -69 & ENEA \\
\hline Revenues & 41 & 9 & 60 & 7 & ENEA \\
\hline Tangible fixed assets & 20 & 12 & 57 & -63 & ENEA \\
\hline \multicolumn{6}{|c|}{ Until 2020} \\
\hline Total balance & 22 & 15 & 65 & -58 & ENEA \\
\hline Equity & -2 & -7 & 31 & -75 & ENEA \\
\hline Revenues & 63 & 11 & 85 & 18 & ENEA \\
\hline Tangible fixed assets & 23 & 25 & 56 & -69 & ENEA \\
\hline \multicolumn{6}{|c|}{ In 2020} \\
\hline Total balance & 5 & -6 & -9 & -8 & PGE \\
\hline Equity & 1 & -14 & 3 & -19 & ENEA \\
\hline Revenues & 22 & 2 & 15 & -23 & PGE \\
\hline Tangible fixed assets & 3 & 11 & -1 & -15 & Tauron \\
\hline
\end{tabular}

The analysis of fundamental economic categories describing business activity indicates the ENEA Group as a leader, both until 2019 and with the volumes achieved in 2020 (Table 17). The ENEA group maintained growth in the level of equity in 2020. The leader in terms of property, plant, and equipment changes was the Tauron group, and in terms of generated revenues and total assets - the PGE group, The worst-ranked performer is the ZEPAK group, whose scale of operations decreased in every aspect except for payments. Furthermore, for the ZE PAK group, there were declines in all analyzed categories in the year of the pandemic occurrence. It should be mentioned that the group closed two power plants in both 2018 and 2020, and these circumstances were not related to the pandemic. They resulted from the group's implementation of its system transformation policy. In 2020, the PGE group recorded increases in all of the volumes studied.

In terms of profitability, the best performers are PGE and Enea (Table 18). PGE showed a lack of profitability in 2015 and 2019 when it made write-downs on fixed assets. In 2020, these ratios took a higher level 2019. On the other hand, ENEA showed a lack of profitability for the same reason as PGE in 2015 and 2019. 
Table 18. Profitability ratios of capital groups from 2014 to 2020.

\begin{tabular}{|c|c|c|c|c|c|}
\hline Year & Profitability Ratios & PGE & Tauron & ENEA & ZE PAK \\
\hline \multirow[t]{6}{*}{2014} & EBITDA profitability ratio & $28.85 \%$ & $19.52 \%$ & $19.43 \%$ & $18.67 \%$ \\
\hline & Return on Assets & $5.52 \%$ & $3.43 \%$ & $5.02 \%$ & $1.14 \%$ \\
\hline & Return on Equity & $8.15 \%$ & $6.59 \%$ & $7.54 \%$ & $2.05 \%$ \\
\hline & Net profit margin & $12.99 \%$ & $6.38 \%$ & $9.04 \%$ & $2.93 \%$ \\
\hline & Gross profit margin & $16.39 \%$ & $8.06 \%$ & $11.37 \%$ & $3.66 \%$ \\
\hline & Gross profit margin on sales & $22.77 \%$ & $15.76 \%$ & $12.00 \%$ & $8.51 \%$ \\
\hline \multirow[t]{6}{*}{2015} & EBITDA profitability ratio & $28.83 \%$ & $-0.37 \%$ & $6.38 \%$ & $-48.00 \%$ \\
\hline & Return on Assets & $-4.95 \%$ & $-5.63 \%$ & $-1.74 \%$ & $-37.79 \%$ \\
\hline & Return on Equity & $-7.51 \%$ & $-11.24 \%$ & $-3.29 \%$ & $-99.73 \%$ \\
\hline & Net profit margin & $-10.64 \%$ & $-9.82 \%$ & $-3.96 \%$ & $-63.77 \%$ \\
\hline & Gross profit margin & $-13.16 \%$ & $-11.91 \%$ & $-4.06 \%$ & $-62.19 \%$ \\
\hline & Gross profit margin on sales & $-5.34 \%$ & $-4.17 \%$ & $-26.00 \%$ & $-57.78 \%$ \\
\hline \multirow[t]{6}{*}{2016} & EBITDA profitability ratio & $26.26 \%$ & $14.00 \%$ & $19.81 \%$ & $21.42 \%$ \\
\hline & Return on Assets & $3.80 \%$ & $1.11 \%$ & $3.46 \%$ & $5.21 \%$ \\
\hline & Return on Equity & $6.00 \%$ & $2.22 \%$ & $6.52 \%$ & $11.68 \%$ \\
\hline & Net profit margin & $33.12 \%$ & $20.09 \%$ & $23.52 \%$ & $19.88 \%$ \\
\hline & Gross profit margin & $3.70 \%$ & $3.86 \%$ & $4.11 \%$ & $4.12 \%$ \\
\hline & Gross profit margin on sales & $5.75 \%$ & $7.65 \%$ & $8.32 \%$ & $8.11 \%$ \\
\hline \multirow[t]{6}{*}{2017} & EBITDA profitability ratio & $11.55 \%$ & $7.94 \%$ & $9.99 \%$ & $7.51 \%$ \\
\hline & Return on Assets & $14.24 \%$ & $10.09 \%$ & $12.58 \%$ & $10.59 \%$ \\
\hline & Return on Equity & $23.74 \%$ & $16.71 \%$ & $9.00 \%$ & $16.69 \%$ \\
\hline & Net profit margin & $24.57 \%$ & $13.86 \%$ & $19.84 \%$ & $-12.22 \%$ \\
\hline & Gross profit margin & $1.99 \%$ & $0.56 \%$ & $2.40 \%$ & $-11.98 \%$ \\
\hline & Gross profit margin on sales & $3.16 \%$ & $1.12 \%$ & $4.78 \%$ & $-27.48 \%$ \\
\hline \multirow[t]{6}{*}{2018} & EBITDA profitability ratio & $5.82 \%$ & $1.14 \%$ & $5.56 \%$ & $-20.12 \%$ \\
\hline & Return on Assets & $8.45 \%$ & $2.78 \%$ & $6.72 \%$ & $-22.36 \%$ \\
\hline & Return on Equity & $18.89 \%$ & $9.30 \%$ & $7.00 \%$ & $-14.02 \%$ \\
\hline & Net profit margin & $-11.10 \%$ & $11.69 \%$ & $21.55 \%$ & $-8.35 \%$ \\
\hline & Gross profit margin & $-5.06 \%$ & $-0.03 \%$ & $1.65 \%$ & $-14.31 \%$ \\
\hline & Gross profit margin on sales & $-9.11 \%$ & $-0.06 \%$ & $3.49 \%$ & $-37.92 \%$ \\
\hline \multirow[t]{6}{*}{2019} & EBITDA profitability ratio & $-10.44 \%$ & $-0.06 \%$ & $3.41 \%$ & $-15.50 \%$ \\
\hline & Return on Assets & $-12.50 \%$ & $-0.08 \%$ & $5.49 \%$ & $-15.29 \%$ \\
\hline & Return on Equity & $-6.66 \%$ & $6.37 \%$ & $13.00 \%$ & $-10.70 \%$ \\
\hline & Net profit margin & $3.08 \%$ & $4.61 \%$ & $-0.60 \%$ & $-6.25 \%$ \\
\hline & Gross profit margin & $0.18 \%$ & $-6.31 \%$ & $-7.48 \%$ & $-7.87 \%$ \\
\hline & Gross profit margin on sales & $0.34 \%$ & $-15.16 \%$ & $-17.06 \%$ & $-23.85 \%$ \\
\hline \multirow[t]{6}{*}{2020} & EBITDA profitability ratio & $0.32 \%$ & $-12.21 \%$ & $-12.25 \%$ & $-10.26 \%$ \\
\hline & Return on Assets & $0.69 \%$ & $-8.13 \%$ & $-14.27 \%$ & $-13.73 \%$ \\
\hline & Return on Equity & $9.08 \%$ & $-1.30 \%$ & $-29.00 \%$ & $-10.88 \%$ \\
\hline & Net profit margin & $0.32 \%$ & $-12.21 \%$ & $-12.25 \%$ & $-10.26 \%$ \\
\hline & Gross profit margin & $0.69 \%$ & $-8.13 \%$ & $-14.27 \%$ & $-13.73 \%$ \\
\hline & Gross profit margin on sales & $9.08 \%$ & $-1.30 \%$ & $-29.00 \%$ & $-10.88 \%$ \\
\hline
\end{tabular}

Own study.

The Tauron group's profitability ratios deteriorated in 2020 compared to 2019. ZEPAK reported losses in 2018, 2019, and 2020, with the most significant losses in 2018 and lower in 2020 than in 2019 (Table 18). The results included in Table 18 are presented in Figure 2. 


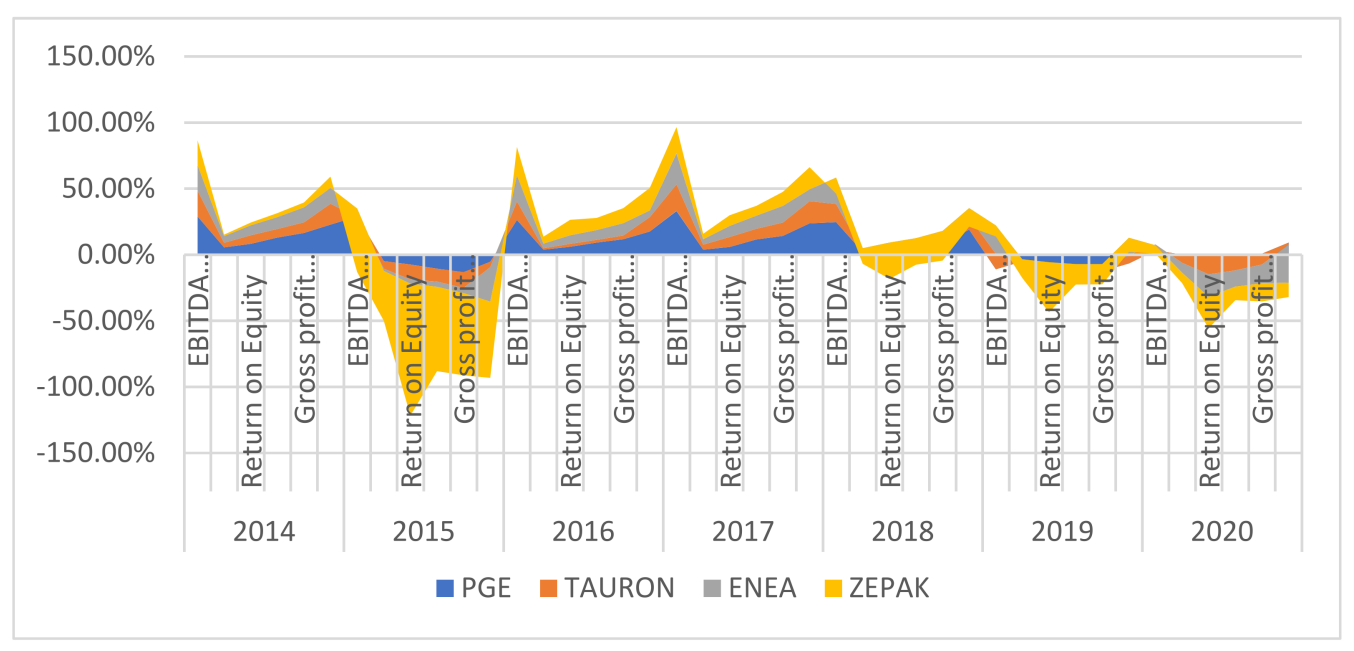

Figure 2. Profitability ratios of capital groups in the years 2014-2020 (Own study).

Profitability ratios achieved by the Generation segment are presented in Figure 2 and Table 19. The highest average EBITDA ratio is PGE $(26 \%)$, followed by ENEA, Tauron, and ZE PAK $(18,15$, and 13\%). The assets of the PGE group have the highest capacity to generate profits, followed by the ENEA and Tauron groups.

Table 19. Profitability indicators of the production segment in the researched group.

\begin{tabular}{|c|c|c|c|c|c|c|c|c|}
\hline Group & Profitability Ratios & 2014 & 2015 & 2016 & 2017 & 2018 & 2019 & 2020 \\
\hline \multirow[t]{6}{*}{ PGE } & EBITDA profitability ratio & 0.39 & 0.40 & 0.37 & 0.32 & 0.19 & 0.15 & 0.10 \\
\hline & Return on Assets & 0.06 & -0.05 & 0.04 & 0.03 & 0.02 & -0.05 & 0.00 \\
\hline & Return on Equity & 0.08 & -0.07 & 0.05 & 0.04 & 0.02 & -0.08 & 0.00 \\
\hline & Net profit margin & 0.18 & -0.15 & 0.13 & 0.11 & 0.05 & -0.08 & 0.00 \\
\hline & Gross profit margin & 0.22 & -0.18 & 0.16 & 0.14 & 0.07 & -0.10 & 0.01 \\
\hline & Gross profit margin on sales & -0.03 & -0.42 & 0.17 & 0.19 & 0.12 & -0.18 & 0.06 \\
\hline \multirow[t]{6}{*}{ Tauron } & EBITDA profitability ratio & 0.16 & 0.14 & 0.13 & 0.12 & 0.16 & 0.23 & 0.14 \\
\hline & Return on Assets & 0.01 & -0.32 & 0.06 & 0.01 & 0.02 & -0.01 & -0.27 \\
\hline & Return on Equity & 0.01 & -0.38 & 0.08 & 0.01 & 0.02 & -0.01 & -0.34 \\
\hline & Net profit margin & 0.01 & -0.65 & 0.16 & 0.02 & 0.04 & -0.03 & -0.72 \\
\hline & Gross profit margin & 0.01 & -0.65 & 0.16 & 0.02 & 0.04 & -0.03 & -0.72 \\
\hline & Gross profit margin on sales & 0.01 & -0.65 & -0.17 & 0.00 & 0.03 & -0.04 & -0.72 \\
\hline \multirow[t]{6}{*}{ ENEA } & EBITDA profitability ratio & 0.21 & 0.25 & 0.16 & 0.16 & 0.12 & 0.20 & 0.18 \\
\hline & Return on Assets & 0.04 & -0.02 & 0.02 & 0.02 & 0.02 & 0.02 & -0.11 \\
\hline & Return on Equity & 0.04 & -0.02 & 0.02 & 0.02 & 0.02 & 0.02 & -0.11 \\
\hline & Net profit margin & 0.10 & -0.05 & 0.06 & 0.07 & 0.04 & 0.03 & -0.12 \\
\hline & Gross profit margin & 0.12 & -0.05 & 0.07 & 0.09 & 0.04 & 0.05 & -0.14 \\
\hline & Gross profit margin on sales & 0.12 & -0.26 & 0.05 & 0.09 & 0.07 & 0.13 & -0.29 \\
\hline \multirow[t]{6}{*}{ ZE PAK } & EBITDA profitability ratio & 0.17 & 0.12 & 0.17 & 0.18 & 0.05 & 0.14 & 0.06 \\
\hline & Return on Assets & $\mathrm{n} / \mathrm{a}$ & $\mathrm{n} / \mathrm{a}$ & $\mathrm{n} / \mathrm{a}$ & $\mathrm{n} / \mathrm{a}$ & $\mathrm{n} / \mathrm{a}$ & $\mathrm{n} / \mathrm{a}$ & $\mathrm{n} / \mathrm{a}$ \\
\hline & Return on Equity & $\mathrm{n} / \mathrm{a}$ & $\mathrm{n} / \mathrm{a}$ & $\mathrm{n} / \mathrm{a}$ & $\mathrm{n} / \mathrm{a}$ & $\mathrm{n} / \mathrm{a}$ & $\mathrm{n} / \mathrm{a}$ & $\mathrm{n} / \mathrm{a}$ \\
\hline & Net profit margin & 0.03 & -0.47 & 0.08 & 0.09 & -0.10 & -0.17 & -0.03 \\
\hline & Gross profit margin & 0.03 & -0.87 & 0.10 & 0.12 & -0.13 & -0.17 & -0.08 \\
\hline & Gross profit margin on sales & 0.05 & -0.84 & 0.14 & 0.14 & -0.08 & -0.14 & -0.08 \\
\hline
\end{tabular}

Own study.

The EBIDA ratio was profitable in all groups and in all periods. Thus, in the PGE group it took a clear decreasing trend, in the Tauron and ZE PAK groups a less clear trend. In the Tauron group, the highest occurred in 2019 (Figure 3). 


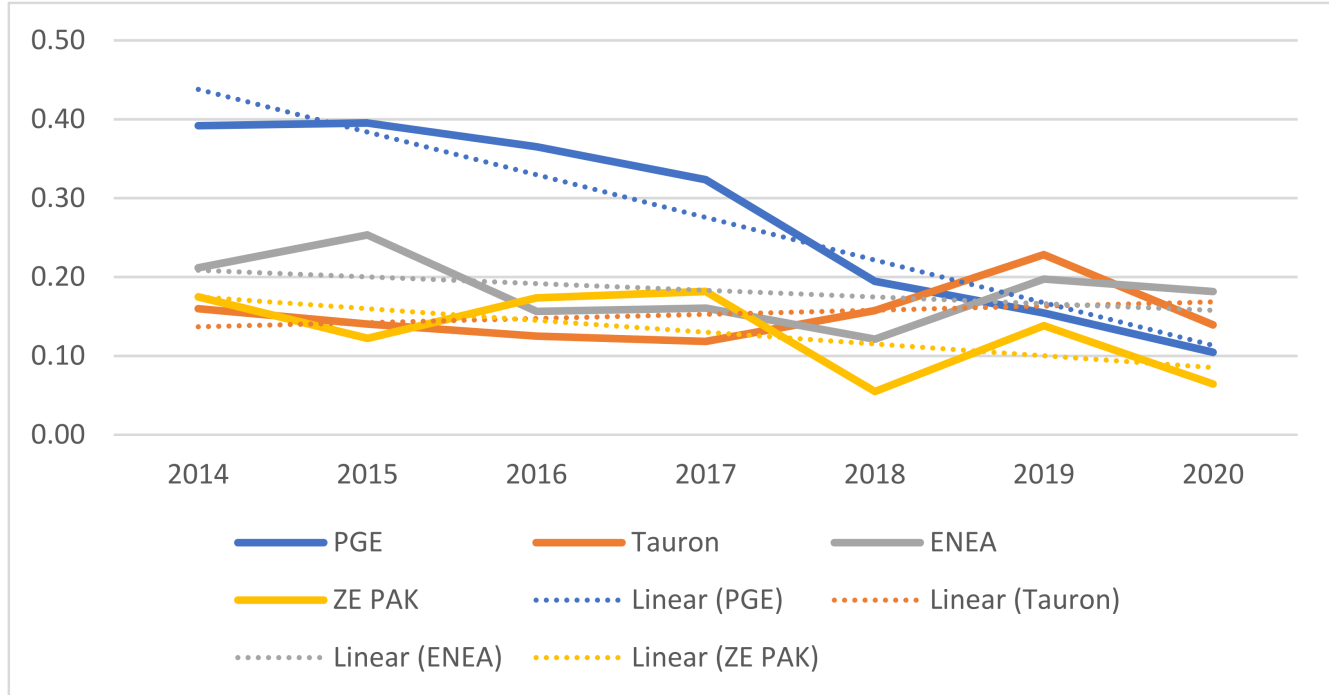

Figure 3. EBITDA ratios of the segments under review (Own study).

The values of other financial ratios were within the allowed ranges. A decrease in liquidity ratios can be observed. However, they are within the recommended range.

The financial performance of the group companies was shaped by several groups of factors: political, Market, and climate protection.

Political factors had an impact on the value of revenues achieved by the group companies, as on 28 December 2018, the Law on Amendments to the Excise Tax Law and Certain Other Laws was [58]. This Act was intended to stabilize the sales price of electricity to the end-user in 2019. Among other things, the law froze the level of electricity prices for end-users, and for retail companies, it introduced a compensation system.

In 2015, the prolonged unfavorable market situation for electricity generators and the resulting adoption of more cautious electricity price forecasts in the future influenced the creation of impairment losses on assets.

On the cost side, the growing prices of $\mathrm{CO}_{2}$ emission permits had an impact. This factor becomes particularly important because in 2015, the ZEPAK Group purchased almost the entire amount of $\mathrm{CO}_{2}$ emission permits, which is reflected in the growing importance of this factor in the cost structure.

Market and environmental factors particularly influenced the impairment of property, Plant, and equipment in 2015 and 2019 or 2020. The most significant factors for the creation of write-downs were the following:

- $\quad$ Rapid changes in the commodity markets, which affected price declines for almost all energy commodities in global markets;

- Long-term persistent market value of net assets at levels below the carrying value of net assets;

- Reduced future electricity generation;

- Faster than anticipated retirement of older generating units.

Additionally, there were circumstances in 2020 that increased the impairment charges. These included:

- High volatility of energy prices in the forward market;

- A decline in domestic electricity consumption due to increased winter 2019/2020 temperatures and the impact of the COVID-19 pandemic;

- Regulatory actions to limit energy price increases for end customers;

- Increased risk in commercial coal production;

- RES auctions and the very dynamic development of the prosumer and micro-installation sub-sector due to the support programs launched; 
- Consequences of the introduction of the provisions of the winter package, including the emission standard, adversely affecting the possibility of participation in the power market of coal units after 1 July 2025;

- Tightening of emission standards and persistently unfavorable market conditions from the point of view of the profitability of conventional power generation;

- Decline in the risk-free rate.

- The need to write down assets in 2020 resulted in particular:

- From an increase in $\mathrm{CO}_{2}$ emission allowance prices as a result of a change like the market, the reform of the $\mathrm{EU} \mathrm{CO}_{2}$ emission allowance trading system (EU ETS), as well as the European Union's climate policy, strongly focused on accelerating the pace of decarbonization in pursuit of Europe's climate neutrality as a realization of the European Green Deal,

- Projected decline in market margins in the short and medium-term as a result of rising $\mathrm{CO}_{2}$ emission allowance prices and the increasing share of renewable energy sources and new, more efficient conventional sources in the domestic energy mix, which negatively impacts the projected electricity prices

- Decreased projected demand for steam coal due to progressive decarbonization in Europe and reduced operation period of hard coal mines in connection with adjustment to Poland's energy policy.

Unfavorable trends in external factors forced us to perform asset impairment tests. As a result of the analyses, the carrying value of generation and mining assets was reduced, which unfortunately harmed the financial results achieved in 2015 and 2019 or 2020, depending on the group. These operations did not affect the groups' liquidity.

In order to verify the hypothesis, it was necessary to examine the amount of financial expenditures for development. The PGE Group incurred the most capital expenditures in the generation segment. Tauron and Enea groups incurred four times less expensive than PGE. The financial statements of the ZE PAK group lack information on the expenditures incurred for individual operating segments. For this reason, information on the amounts of purchased property, plant, and equipment and performed overhauls attributed to the generation segment was used in the analysis (Table 20).

Table 20. Investment expenditure in PLN million.

\begin{tabular}{lccccccc}
\hline Group & $\mathbf{2 0 1 4}$ & $\mathbf{2 0 1 5}$ & $\mathbf{2 0 1 6}$ & $\mathbf{2 0 1 7}$ & $\mathbf{2 0 1 8}$ & $\mathbf{2 0 1 9}$ & $\mathbf{2 0 2 0}$ \\
\hline PGE & 4736 & 7426 & 6323 & 4980 & 4998 & 4167 & 3026 \\
Tauron & 404 & 1934 & 1661 & 1517 & 1300 & 1683 & 1377 \\
ENEA & 1846 & 1955 & 1390 & 1094 & 430 & 492 & 548 \\
ZE PAK & 694 & 418 & 126 & 108 & 72 & 31 & 1 \\
\hline
\end{tabular}

Own study.

The PGE Capital Group incurred expenses on property, plant, and equipment, mainly on constructing new blocks of highly efficient conventional power generation, modernization of assets of the group's units, and purchase of machinery and equipment. Other significant investments include increasing the efficiency of the existing units and their environmental upgrades. The group is investing in the development of renewable energy sources-onshore and offshore wind farms. On 25 June 2020, two new wind farms were commissioned during the declared epidemic state. Despite the ongoing state of emergency, on 31 December 2020, the PGE Capital Group committed to incur further expenditures for property, plant, and equipment, mainly for the construction of new units, modernization of the assets of the group's teams and purchase of machinery and equipment. The group's further plans are connected with increased power capacity.

Essential capital expenditures in ENEA serve to maintain continuity of operations, ensure the effectiveness of the process of sources, and meet environmental standards. The group optimizes its investment expenditures relating to renewable energy sources, 
cogeneration sources, and heat networks. It focuses on the development of micro-and macro energy clusters, electromobility, and prosumer installations. In the field of renewable energy sources, the group focuses primarily on increasing the operating efficiency of the assets it already owns, seeing its opportunity in the development of hybrid RES [59].

Despite the difficult economic situation, the ZE PAK Group has undertaken modernization and development activities. It is carrying out an investment program encompassing modernization of the power generation assets and replacing worn-out power generation units with modern technologies. It continues with current investments in maintenance of the currently operated open-pit mines and the launch of a highly efficient team generating electricity and heat from a gas/steam unit.

At the beginning of 2018, the Adamów power plant was shut down after more than 50 years of operation. The decrease in production in 2020 occurred not only due to the pandemic but also due to the shutdown on 30 June 2020, of two coal-fired units in the Patnów power plant with a capacity of 200 MW each, commissioned in 1968/69. The shutdowns of the power units naturally resulted in a decrease in the scale of operations of the ZE PAK SA Group.

The Strategic Investment Program for ZE PAK SA, which considers the assumptions of the Polish Energy Policy valid in 2008, was prepared in a period promising favorable conditions for investment in gas-fired equipment. Unfortunately, the Polish economy did not have excellent conditions to construct the steam-gas unit planned for the Adamów power plant. After analyzing the requirements, the decision to develop this project was suspended. During the pandemic in 2020, ZE PAK SA entered into a contract to build the most prominent photovoltaic farm in Poland with a capacity of $70 \mathrm{MWp}$.

Figure 4 compares the capital expenditures incurred in the generation segment with the EBITDA achieved by the elements.

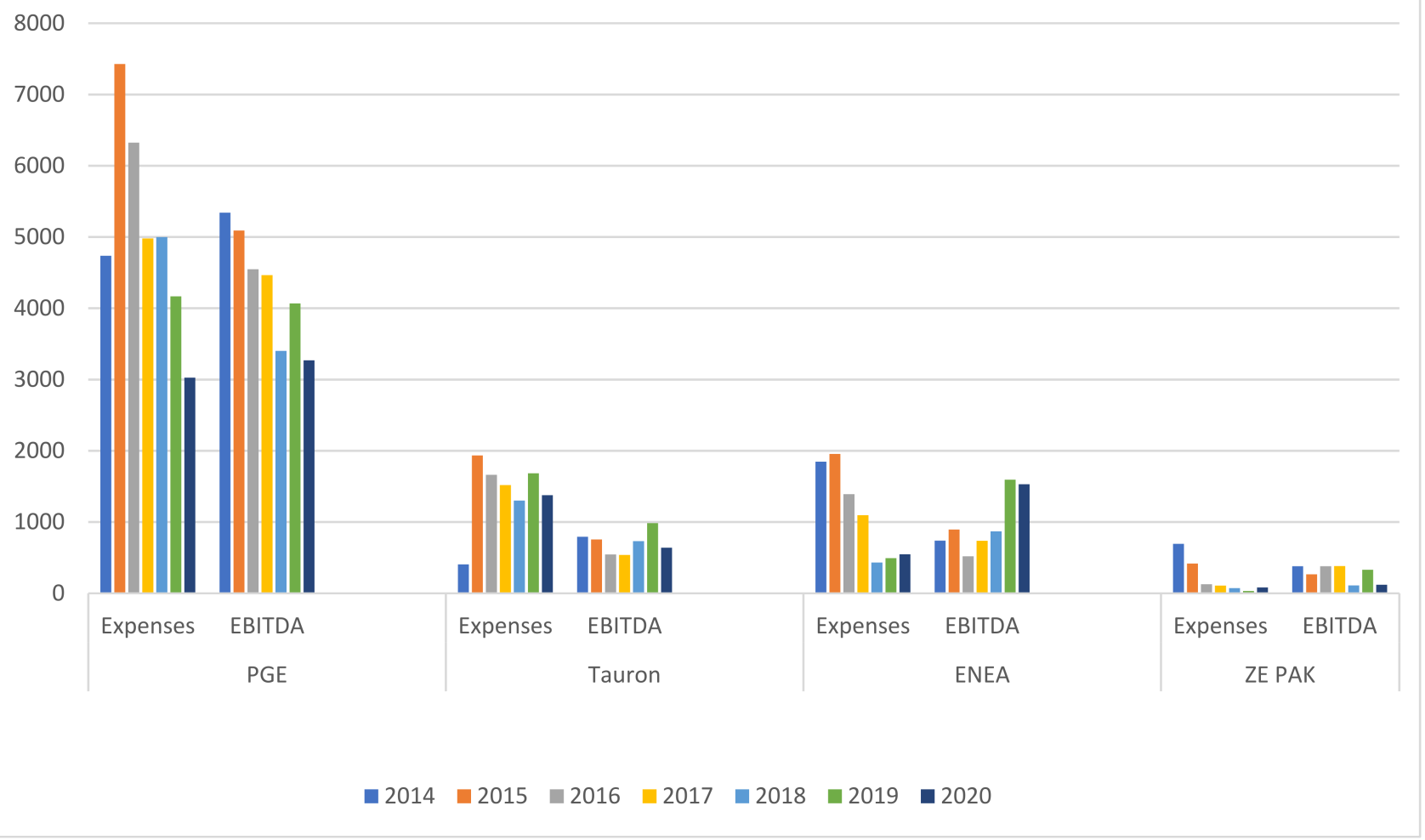

Figure 4. EBITDA ratios of the segments under review (Own study).

Table 21 presents the share of achieved EBITDA in the capital expenditures incurred. 
Table 21. Share of achieved EBITDA in the capital expenditures incurred.

\begin{tabular}{cccccccc}
\hline Group & $\mathbf{2 0 1 4}$ & $\mathbf{2 0 1 5}$ & $\mathbf{2 0 1 6}$ & $\mathbf{2 0 1 7}$ & $\mathbf{2 0 1 8}$ & $\mathbf{2 0 1 9}$ & $\mathbf{2 0 2 0}$ \\
\hline 1 & Tauron & PGE & ZE PAK & ZE PAK & ENEA & ZE PAK & ENEA \\
2 & PGE & ZE PAK & PGE & PGE & ZE PAK & ENEA & ZE PAK \\
3 & ZE PAK & ENEA & ENEA & ENEA & PGE & PGE & PGE \\
4 & ENEA & Tauron & Tauron & Tauron & Tauron & Tauron & Tauron \\
\hline
\end{tabular}

Own study.

An analysis of the capital expenditures incurred by the groups in the generation segment and the EBITDA achieved in these segments shows that the ZEPAK group performs the highest return. Three times in the period under review, it reached the highest share of EBITDA in capital expenditures. The second group with the highest return is the PGE group.

The Pearson correlation of investment expenditures made by the groups in the generation segment with EBITDA showed a moderate correlation in the PGE group $(\mathrm{r}=0.62)$. The correlation strength was also average for the ENEA group, with a negative correlation $(\mathrm{r}=-0.62)$. The correlation study of the two variables in the Tauron group showed no linear relationship $(r=-0.1)$, and for ZE PAK, a weak correlation $(r=0.35)$.

The study of the Spearman correlation coefficient confirmed that in PGE and ZEPAK groups, EBITDA increases moderately and weakly with increased expenses, respectively (Table 22). In Tauron, the relationship is so weak that it can be concluded that it does not exist. In ENEA, there is a negative relationship-in 2014-2017, with high expenses, EBITDA decreases, and in turn, in 2018-2020, with low costs, EBITDA increases. The costs incurred by ENEA are used to maintain the continuity of operations.

Table 22. Spearman correlation coefficient.

\begin{tabular}{ccccc}
\hline & \multicolumn{4}{c}{ Group } \\
\hline \multirow{2}{*}{ Result } & PGE & Tauron & ENEA & ZE PAK \\
& 0.5 & 0.07 & -0.36 & 0.44 \\
\hline Own study.
\end{tabular}

The index analysis is completed by examining the share prices of the capital market indicators of the studied parent companies on the Warsaw Stock Exchange from 1 January 2014 to 31 December 2020. Figure 5 shows the share prices of the companies Polska Grupa Energetyczna, Tauron, ENEA and ZE PAK in the selected period.

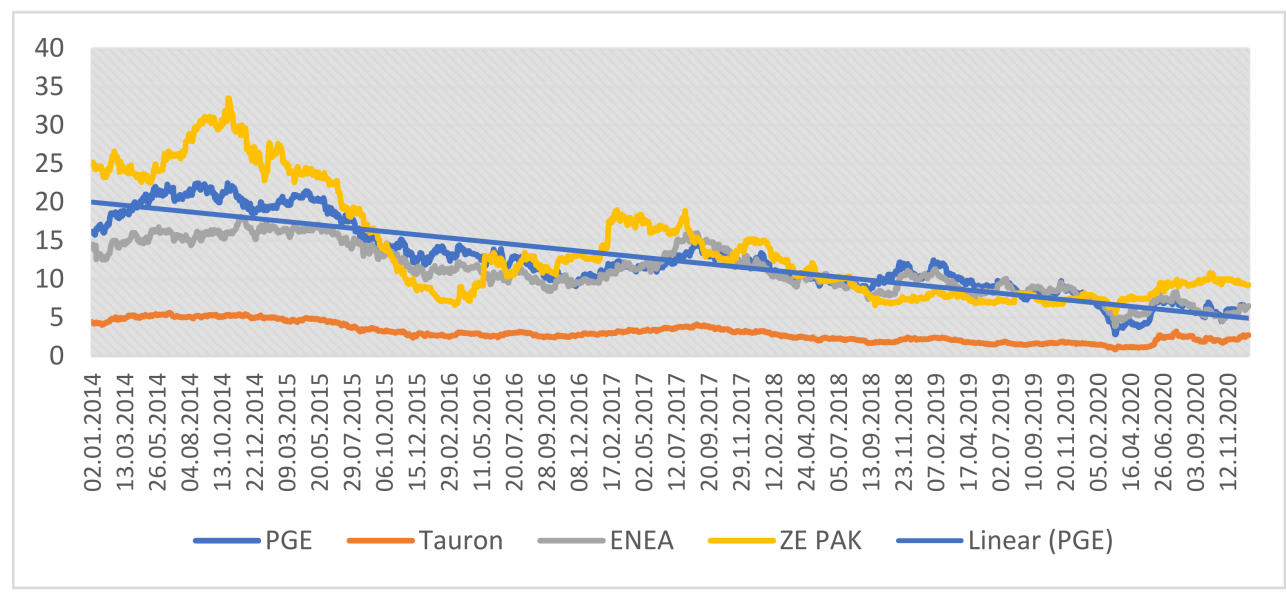

Figure 5. Share prices of PGE, TAURON, ENEA and ZE PAK during the period from 2 January 2014 to 30 December 2020 (Own study based on Warsaw Stock Exchange statistics for 2014-2020). 
Figure 5 shows the unfavorable trends in the share prices of the companies under study. The share value of each company fell below the reference value of 2 January 2014 at the end of the period under study. Table 23 shows selected values from Figure 5.

Table 23. Maxima and minima of the value of shares of the surveyed companies in the examined period.

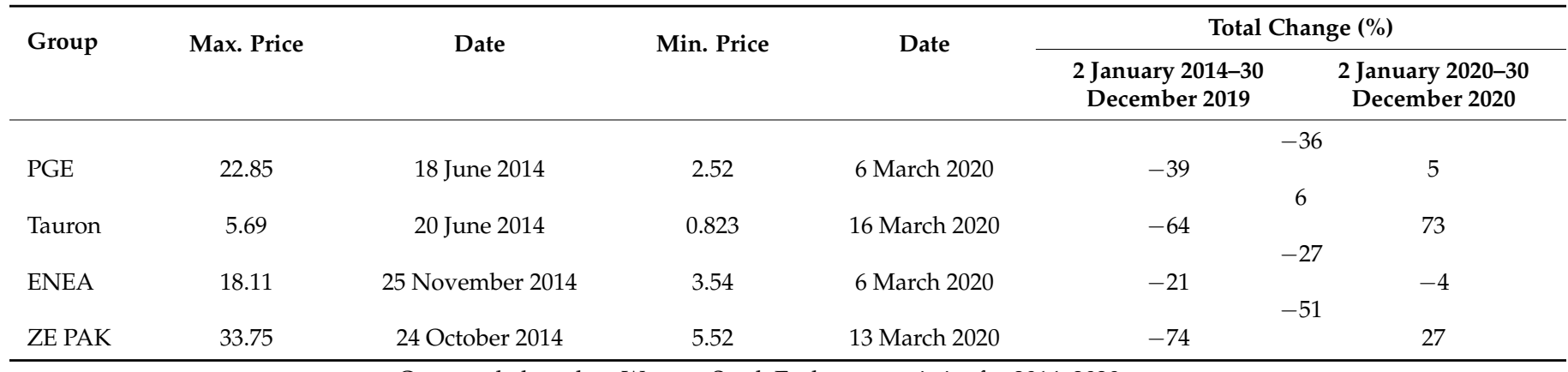

Own study based on Warsaw Stock Exchange statistics for 2014-2020.

Based on the data from the stock exchange, ZE PAK capital group was the worst-rated throughout the period under study. Its shares took the most significant drop in value, the change in the period under study is more than $51 \%$. The share values of the ZE PAK and Tauron group companies by 2019 fell by 74 and 64\%, respectively. At the same time, only in 2020 , the change in the value of Tauron shares occur by $73 \%$, and ZE PAK company by $27 \%$. By 2019, ENEA and PGE group companies' shares were the best valued by the market, with ENEA's share value decreasing by $4 \%$ in 2020 and PGE's increasing by $5 \%$. Throughout the study period, the minimum share values of all companies were recorded in March 2020.

The efficiency of the groups' operations was also examined based on the measure of the market price of shares to the book value of companies (P/BV-price/book value) (Figure 6).

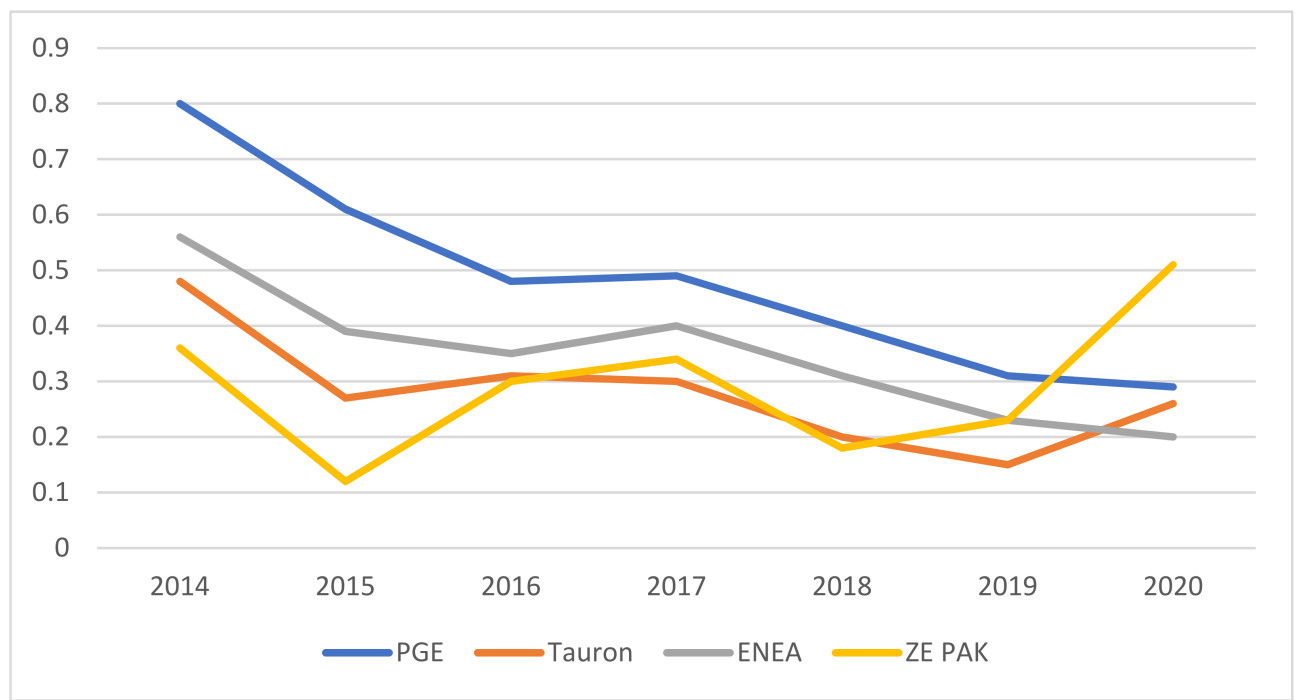

Figure 6. Group functioning efficiency (P/BV) (Own study based on Warsaw Stock Exchange statistics for 2014-2020).

A ratio below unity (Figure 6) indicates undervaluation by the market and poor asset utilization. Among the surveyed groups, PGE achieved the highest percentages. This situation continued in 2019, which means that it invested the most. 
It should be emphasized that share prices depend on many factors, such as the situation on global stock exchanges, forecasts for the sector, the condition of the stock market, the company's development potential, government policy, and others, and not only on the manufacturing activities of the companies under study.

Based on the economic and market situation analysis, it can be noted that the value of market capitalization of groups that own mines remains at a level lower than the carrying value of net assets. It should be noted that this premise was already present at the end of 2019 and was the main reason for performing an impairment test.

In 2020, there was a further, albeit no longer as significant, decline in the share price and thus in the market capitalization. This situation is primarily due to factors beyond the groups' control, such as political factors and EU climate policy, the low liquidity of the shares, and the low level of shares in free float.

\section{Conclusions}

The spread of the SARS-CoV-2 virus causing COVID-19 disease and the numerous restrictions introduced in the country to contain it caused disruptions in Poland's economic and administrative system and the world. The pandemic caused repercussions in the social and economic spheres [60], limiting economic activity to a different extent and affecting the work of industrial plants and companies in the segment of small and medium-sized enterprises [2], therefore it was decided to investigate whether the COVID-19 pandemic contributed to the economic issues of the largest listed energy companies operating in Poland. In order to answer this question, the financial data of the ten largest Polish professional power plants in terms of electricity production, belonging to four capital groups, listed on the stock exchange, were analyzed. The capital groups selected for the study are: Polska Grupa Energetyczna (PGE), Tauron, Enea and Zespół Elektrowni Patnów-AdamówKonin (ZE PAK). The capital groups are the largest producers of electricity in Poland, they own at least one of the ten largest power plants in Poland. The aim of the research was to show that those capital groups which in the period preceding the outbreak of the epidemic made the largest investment outlays and at the same time their financial ratios and market valuation on the Warsaw Stock Exchange were the highest, also during the pandemic achieved the highest financial results - they had the most favorable economic situation. The implementation of the goal confirmed the hypothesis that companies investing in new solutions and technologies are best prepared for crisis situations.

Readings of economic indicators confirmed that the effects of the pandemic have a significant impact on the financial situation. Among other things, the level of industrial production and investment declined, contributing to a decrease in domestic electricity consumption and thus affecting the reduction of electricity production. However, the decline in production in power plants by about $4 \%$ compared to the same period of the previous year is not a significant reduction [60]. Furthermore, the decrease in recorded electricity consumption may be related to increased installed capacities, such as renewable energy sources by prosumers, whose consumption is not directly recorded by metering equipment. The impact of COVID-19 on the financial results of the PGE group in 2020 was limited [61]. Similarly, the ENEA group's business was not materially affected by the risks associated with the virus [62,63] (pp. 124-125). In the first half of 2020, a significant reduction in demand for thermal coal from commercial power and district heating was evident, but this is due to a warm and windy winter. In the third quarter of 2020, non-pandemic factors were joined by geological and mining factors limiting coal yields. These difficulties proved to be temporary [63]. The pandemic did not significantly disrupt production, the supply chain was not interrupted, which was the case and significantly weakened some sectors of the economy, especially exporters in trade relations with Germany and the entire euro area [5]. Although the mining sector-due to the technologies and working conditions used-did not protect itself against the wave of infections of mine workers, the measures taken by the government maintained the continuity of employment. 
Contracts concluded in previous years for the sale of electricity, obtaining a higher average sales price as a result of an increase in tariff rates and higher electricity prices on the market or a higher volume due to assets put into use [64] ad an impact on limiting the impact of the pandemic. In 2020, after freezing electricity prices in 2019, there were significant increases, especially in the group of customers connected to the low voltage network.

The groups' financial results were affected by asset write-downs during the period under review. The pandemic phenomenon was not the primary indication of a possible impairment of non-current assets but only an additional signal, necessitating an impairment test. The impairment losses on fixed assets performed in 2015 by all the companies under review testified that these assets were less adapted to generate revenues in the new realities of the energy sector.

All of the groups studied identify risk factors that may affect financial results due to the COVID-19 pandemic [65] (pp. 61, 98) and closely monitor the situation and the level of this threat while taking numerous measures to minimize adverse effects. Factors that directly affected the business operations of the groups were the increased number of employees on vacation, sick leave, and working remotely through increased employee absenteeism and increased operating costs. Considering the entire value creation chain, the identified factors at the group level in 2020 did not have a material impact. As of 31 December 2020, the result from the anticipated increase in payment congestion, particularly on receivables from small and medium-sized companies, was not material. There was no liquidity risk. However, there is no additional risk of non-payment of receivables above the current level [61] (p. 81) [64], or it was not essential [63].

The pandemic outbreak prompted individual groups to introduce new or changes to existing credit risk management policies. As part of the credit risk management policies changes, the criteria for assigning internal ratings and credit limits to counterparties were changed.

In addition, increased price volatility in the financial and commodity markets, particularly the prices of electricity and carbon emission allowances, are of great importance for the groups as changes in the prices of these instruments affect liquidity and future financial results [66].

As a result of the research, conclusions were drawn that as a result of the pandemic, energy companies adapted their financial strategies and financial risk management strategies. The COVID-19 pandemic also resulted in certain impediments to strategic investment projects. In the case of power unit construction investments, these occurred during the initial period of the pandemic as a result of the implementation of strict infrastructure access controls and additional security procedures.

The pandemic accelerated the introduction of activities related to preparing entire organizations for changes to meet the challenges posed to energy companies related to decarbonization. As a result of the pandemic, all groups surveyed have established crisis teams at the parent company level and at the level of individual subsidiaries. Their purpose is to monitor the situation and prevent negative consequences of the pandemic. The tasks of these teams include, among others, suggesting organizational changes aimed at protecting employees and at the same time guaranteeing continuity of production.

Thus, the COVID-19 pandemic has affected the organization of work, particularly in manufacturing units. In many cases, this involves additional costs, such as the purchase of protective materials for employees.

Since the beginning of the pandemic, groups have implemented work rules to reduce the risk of employee illness as much as possible. They have undertaken work redesign activities to ensure continuity and protect employees' health and lives, including implementing remote and rotating work, building awareness of essential coronavirus protection, prevention, and quarantine. These measures include, but are not limited to, temporarily limiting travel and business meetings, increasing the availability and extent of use of cleaning, disinfecting and protective products, implementing appropriate work procedures (e.g., shift work, disinfecting rooms, placing limits on employees in rooms, maintaining safe 
distances between employees), and monitoring travel destinations of employees, including their families for high-risk countries. In the area of retail customer service, the groups focused primarily on expanding remote service channels.

Organizational adaptation to the new conditions (to the conditions of the pandemic) in conjunction with the investment outlays in the preceding period ensured the continuity of electricity supply. Summarizing, the conducted research must conclude that companies from the energy sector which made the most significant investments achieve the best financial results. It is worth noting that changes in the conditions of the energy market in the area of energy generation technologies and legislative changes shaping the future energy market model force companies operating in the energy sector to adapt by introducing new technologies. Significant throughout the study were the regulatory changes that resulted in two periods: 2015 and 2019 or 2020. All the groups studied took an impairment loss, significantly affecting the results presented in the financial statements. Hence, the objective was to investigate which of the selected generating companies were performing the best and which factors had the greatest impact on the increase or decrease in their performance.

The study of the financial statements of the power generation activities of energy groups confirms the hypothesis that companies investing in new solutions and technologies will be the most effective. In the analyzed period, capital groups that made the largest investments achieved at the same time financial ratios at the appropriate level and the stock exchange valuation was the highest.

Changes in the trend of sales and price fluctuations in the energy market of the countries affected by the pandemic in the first phase of its development were similar. The initial disturbance in energy demand and decline in sales levels subsided after a few months. By the second half of the 2020 year, most of them had achieved sales levels similar to those recorded in the year prior to the pandemic year and, by managing the change efficiently, were ready to operate under further pandemic-induced restrictions. The stability and good financial condition of the sector were confirmed by the share prices of the surveyed companies remaining at similar or even higher levels than before the pandemic. In contrast to the catering, tourism, hotel or training industry, whose revenues decreased year-on-year in some cases by more than $90 \%$, the energy sector ended the first year of the pandemic with rates not significantly different from the forecast.

Uncertainty, which has appeared in almost all sectors of each economy (except the, IT, high-tech or telecommunications sectors), affects the energy sector indirectly, but this impact may be significant and its direction is unknown yet. Critical to national and global economic stability is the targeting of financial support to the industries most affected by the pandemic. This may result in a lack of funds for the originally planned investments in the energy sectors and delay the achievement of the energy mix and $\mathrm{CO}_{2}$ emission reduction targets, or even necessitate a review of the assumptions of the agreements concluded in this area at the international level.

The authors were not able to verify the actual share of RES in energy production due to the lack of figures on energy consumption by prosumers (they are not recorded). Given the scope of the data analysed covering the first year of the pandemic and its expected duration, the study should be continued. The scope of the study was also limited by the scarce availability of literature on the subject (in particular, relating to the response to the pandemic situation in the energy market in Poland), which is mainly due to the nature of the phenomenon under investigation: this is the first ever pandemic with a global reach and, at the same time, such a strong impact on societies and economies.

The analysis of the conclusions and the identified limitations of the study indicate the need to continue the research started by the authors of the article. It is suggested that their scope should be extended to a larger group of companies in the energy sector.

The purpose of this research should be to determine the impact of prosumers' electricity production on the economic situation of energy listed companies. In addition, it seems important to answer the question of how quickly the Polish energy sector will meet its $\mathrm{CO}_{2}$ 
emission reduction commitments, taking into account the current energy mix and costs of necessary investments.

Author Contributions: Conceptualization, A.Ł. and E.R.-T.; formal analysis, A.Ł.; funding acquisition, A.Ł. and E.R.-T. and M.S.; investigation, A.Ł.; methodology, A.Ł.; project administration, A.Ł.; resources, A.Ł. and E.R.-T. and M.S.; software, A.Ł. and M.S.; supervision, A.Ł.; validation, A.Ł. and E.R.-T. and M.S.; visualization, A.Ł.; writing—original draft, A.Ł.; writing-review \& editing, A.Ł. and E.R.-T. and M.S. All authors have read and agreed to the published version of the manuscript.

Funding: This research received no external funding.

Institutional Review Board Statement: Not applicable.

Informed Consent Statement: Not applicable.

Data Availability Statement: The data presented in this study are available on request from the corresponding author.

Conflicts of Interest: The authors declare no conflict of interest.

\section{References}

1. Menkes, J.; Suska, M. The EU funds for addressing the consequences of the COVID-19 pandemic: Implications for Poland. In The Economic and Legal Impact of COVID-19; Menkes, J., Suska, M., Eds.; The Case of Poland; Routlege: Abingdon, UK, 2021; pp. 66-84.

2. Czech, K.; Karpio, A.; Wielechowski, M. Polish Economy in the Early Stages of the COVID-19 Pandemic; SGGW: Warsaw, Poland, 2021; pp. 10-25. Available online: https://www.ieif.sggw.pl/wp-content/uploads/2021/04/Polska-gospodarka-w-pocz\%C4\% 85tkowym-okresie-pandemii-COVID-19.pdf (accessed on 14 November 2021).

3. Błoński, Ł.; Dębkowska, K.; Kubisiak, A.; Leśniewicz, F.; Szymańska, A.; Śliwowski, P.; Święcicki, I.; Zybertowicz, K. Pandenomics 2.0. How Countries Faced the Second Wave of Pandemic and the Second Dip of the Recession; Polish Economic Institute: Warsaw, Poland, 2021; pp. 1-15.

4. Wilczewski, N.; Bryk, M. Geographical differentiation of the Polish foreign trade and the impact of the COVID-19 pandemic. Myśl Ekon. I Polit. 2020, 2, 34-54.

5. Męcina, J.; Potocki, P. The Impact of COVID-19 on Poland's Economy and Labor Market-An Excerpt from the Research Report; Open Eyes Economic Summit: Kraków, Poland, 2020; pp. 1-21.

6. Donaj, Ł.; Hajder, K.; Kacperska, M. Consequences of the COVID-19 Pandemic: World and Economy; Wydawnictwo Naukowe Wydziału Nauk Politycznych i Dziennikarstwa: Poznań, Poland, 2020.

7. Taclinkg Coronavirus (COVID-19) Contributing to a Global Effort. Available online: http://mneguidelines.oecd.org/COVID-19and-RBC-Summary-Polish.pdf (accessed on 14 November 2021).

8. Pandenomics 2.0 How Countries Faced the Second Wave of Pandemic and the Second Dip of the Recession. Available online: https:/ / pie.net.pl/pandenomics-2-0-prezentacja-i-debata/ (accessed on 14 November 2021).

9. Baker, S.; Bloom, N.; Davis, S.; Terry, S. COVID-Induced Economic Uncertainty; National Bureau of Economic Research: Cambridge, MA, USA, 2020; Available online: https:/ / www.nber.org/papers/w26983 (accessed on 14 November 2021).

10. Teresiene, D.; Keliuotyte-Staniuleniene, G.; Liao, Y.; Koleśnik, R.; Pu, R.; Hu, S.; Yue, X.-G. The Impact of the COVID-19 Pandemic on Consumer and Business Confidence Indicators. J. Risk Finacial Manag. 2021, 14, 159. [CrossRef]

11. Wielen, W.; van der Barrios, S. Economic sentiment during the COVID pandemic: Evidence from search behaviour in the EU. J. Econ. Bus. 2021, 115, 105970.

12. Kanapickiene, R.; Teresiene, D.; Budriene, D.; Keliuotyte-Staniuleniene, G.; Kartasova, J. The impact of COVID-19 on European financial markets and economic sentiment. Econ. Bus. 2020, 14, 144-163.

13. Njindan Iyke, B. The disease outbreak channel of exchange rate return predictability: Evidence from COVID-19. Emerg. Mark. Financ. Trade 2020, 56, 2277-2297. [CrossRef]

14. Shen, H.; Fu, M.; Pan, H.; Yu, Z.; Chen, Y. The impact of the COVID-19 pandemic on firm performance. Emerg. Mark. Financ. Trade 2020, 56, 2213-2230. [CrossRef]

15. Haydon, D.; Kumar, N.; Industries Most and Least Impacted by COVID-19 from a Probability of Default Perspective-September 2020 Update. SP Glob. Mark. Intell. 2020. Available online: https:/ /www.spglobal.com/marketintelligence/en/news-insights/b $\mathrm{log}$ /industries-most-and-least-impacted-by-covid19-from-a-probability-of-default-perspective-september-2020-update (accessed on 14 November 2021).

16. Parker, K.; Minkin, R.; Bennett, J.; Economic Fallout From COVID-19 Continues To Hit Lower-Income Americans the Hardest. Pew Res. Cent. 2020. Available online: https:/ /www.pewresearch.org/social-trends/2020/09/24/economic-fallout-from-covid -19-continues-to-hit-lower-income-americans-the-hardest/ (accessed on 14 November 2021).

17. Mazur, M.; Dang, M.; Vega, M. COVID-19 and the March 2020 stock market crash. Evidence from S\&P1500. Financ. Res. Lett. 2021, 38, 101690. 
18. Al-Awadhi, A.M.; Al-Saifi, K.; Al-Awadhi, A.; Alhamadi, S. Death and contagious infectious diseases: Impact of the COVID-19 virus on stock market returns. J. Behav. Exp. Financ. 2020, 27, 100326. [CrossRef]

19. Ashraf, B.N. Economic impact of government interventions during the COVID-19 pandemic: International evidence from financial markets. J. Behav. Exp. Financ. 2020, 27, 100371. [CrossRef] [PubMed]

20. Yahya, F.; Shaohua, Z.; Abbas, U.; Waqas, M. COVID-19-induced Returns, Attention, Sentiments and Social Isolation: Evidence from Dynamic Panel Model. Glob. Bus. Rev. 2021. Available online: https://doi.org/10.1177/0972150921996174 (accessed on 14 November 2021). [CrossRef]

21. Akhtaruzzaman, M.; Boubaker, S.; Sensoy, A. Financial contagion during COVID-19 crisis. Financ. Res. Lett. 2021, 38 , 101604. [CrossRef] [PubMed]

22. Ali, M.; Alam, N.; Rizvi, S.A.R. Coronavirus (COVID-19)—An epidemic or pandemic for financial markets. J. Behav. Exp. Financ. 2020, 27, 100341. [CrossRef]

23. Liu, H.; Manzoor, A.; Wang, C.; Zhang, L.; Manzoor, Z. The COVID-19 Outbreak and Affected Countries Stock Markets Response. Int. J. Environ. Res. Public Health 2020, 17, 2800. [CrossRef] [PubMed]

24. Baldwin, R.; Tomiura, E. Thinking ahead about the trade impact of COVID-19. In Economics in the Time of COVID-19; Baldwin, R., di Mauro, B.W., Eds.; CEPR Press: London, UK, 2020; Available online: https://voxeu.org/system/files/epublication/COVID19.pdf (accessed on 14 November 2021).

25. Balloch, C.; Djankov, S.; Gonzalez-Uribe, J.; Vayanos, D. A Restart Procedure to Deal with COVID-19; Special Paper 254; LSE Financial Markets Group Paper Series; Financial Markets Group; The London School of Economics and Political Science; London, UK. 2020, p. 1. Available online: https:/ /www.fmg.ac.uk/sites/default/files/publications/SP254.pdf (accessed on 13 November 2021).

26. Ambroziak, A.A. Financial measures adopted in Poland in the light of COVID-19 state aid EU framework. In The Economic and Legal Impact of COVID-19; Menkes, J., Suska, M., Eds.; The Case of Poland; Routlege: Abingdon, UK, 2021; pp. 85-107.

27. Buendia, J.L.; Dovalo, A. State Aid Versus COVID-19. The Commision Adopts a Temporary Framework. Eur. State Law Q. 2020, 3 , 3-7. [CrossRef]

28. Ferri. D. The Role of EU State Aid Law as a "Risk Management Tool" in the COVID-19 Crisis. Eur. J. Risk Regul. 2021, 12, 176-195. [CrossRef]

29. Dyczkowska, J. The Impact of CIVID-19 on Accounting, Business Practice and Education; Wroclaw University of Econimics and Business: Wroclaw, Poland, 2021.

30. Nicolaides, P. State Aid to Combat COVID-19. Luiss Sch.Eur. Political Econ. 2020. Available online: https://sep.luiss.it/sites/sep.1 uiss.it/files/State\%20Aid\%20to\%20Combat\%20Covid-19.pdf (accessed on 8 November 2021).

31. Filonchyk, M.; Hurynovich, V.; Yan, H. Impact of COVID-19 lockdown on air quality in the Poland, Eastern Europe. Environ. Res. 2021, 198, 110454. [CrossRef]

32. The Great Lockdown: Impact of the COVID-19 Pandemic on the Global Economy. Available online: https://pism.pl/publicatio ns/The_Great_Lockdown_Impact_of_the_COVID19_Pandemic_on_the_Global_Economy (accessed on 5 November 2021).

33. Herrero, A.G. The pandemic requires a coordinated global economic response. Intereconomics 2020, 55, 66-67. [CrossRef]

34. Altig, D.; Baker, S.; Barrero, J.M.; Bloom, N.; Bunn, P.; Chen, S.; Davis, S.J.; Leather, J.; Meyer, B.; Mihaylov, E.; et al. Economic uncertainty before and during the COVID-19 pandemic. J. Public Econ. 2020, 191, 104274. [CrossRef]

35. Carrecedo, P.; Puertas, R.; Marti, L. Research lines on the impact of the COVID-19 pandemic on business. A text mining analysis. J. Bus. Res. 2021, 132, 586-593. [CrossRef]

36. Markovic, S.; Koporcic, N.; Arslanagic-Kalajdzic, M.; Kadic-Maglajlic, S.; Bagherzadeh, M.; Islam, N. Business-to-business open innovation: COVID-19 lessons for small and medium-sized enterprises from emerging markets. Technol. Forecast. Soc. Chang. 2021, 170, 120883. [CrossRef]

37. Jiang, J.; Hou, J.; Wang, C.; Liu, H. COVID-19 impact on firm investment-Evidence from Chinese publicly listed firms. J. Asian Econ. 2021, 75, 101320. [CrossRef]

38. Shiwei, H.; Yuyao, Z. COVID-19 pandemic and firm performance: Cross-country evidence. Int. Rev. Econ. Financ. Elsevier 2021, $74,365-372$.

39. The Impact of COVID-19 on the Electricity Sector-What Should we Expect? Available online: https://www.ey.com/pl_pl/cov id-19/wplyw-covid-19-na-sektor-elektroenergetyczny (accessed on 30 October 2021).

40. Koryś, P. Economic consequences of a pandemic-a review of information and literature. Electr. Power Eng. Mod. Dev. 2020. nr 1. Available online: https:/ / www.pse.pl/documents/20182/334148711/ELEKTROENERGETYKA_EWiR_22_1_2020.pdf (accessed on 29 October 2021).

41. COVID-19 Impact on Electricity. Available online: https:/ /www.iea.org/reports/covid-19-impact-on-electricity (accessed on 25 October 2021).

42. Kanda, W.; Kivimaa, P. What opportunities could the COVID-19 outbreak offer for sustainability transitions research on electricity and mobility? Energy Res. Soc. Sci. 2020, 68, 101666. [CrossRef]

43. Mylenka, T.; Novyk, B. Impact of COVID-19 on the Global Energy Sector. Available online: https://www.pv-magazine.com/20 20/04/24/impact-of-covid-19-on-the-global-energy-sector/ (accessed on 28 October 2021).

44. Bulut, M. Analysis of the Covid-19 Impact on Electricity Consumption and Production. Sak. Univ. J. Comput. Inf. Sci. 2020, 3, 284-295. 
45. Cheshmehzangi, A. COVID-19 and household energy implications: What are the main impacts on energy use? Heliyon 2020, 6, e05202. [CrossRef] [PubMed]

46. Mahajan, M. Estimating U.S. Energy Demand and Emissions impacts of COVID-19 with the Energy Policy Simulator; Energy Innovation: San Francisco, CA, USA, 2020.

47. Prol, J.L.; Sungmin, O. Impact of COVID-19 Measures on Short-Term Electricity Consumption in the Most Affected EU Countries and USA States. Iscience 2020, 23, 101639. [CrossRef] [PubMed]

48. Filonchyk, M.; Hurynovich, V.; Yan, H. Impact of COVID-19 Pandemic on Air Pollution in Poland Based on Surface Measurements and Satellite Data. Aerosol Air Qual. Res. 2020, 21, 200472. [CrossRef]

49. Honore, A. The Oxford Institute For Energy Studies. 2020. Available online: https://www.oxfordenergy.org/publications/natu ral-gas-demand-in-europe-the-impacts-of-covid-19-and-other-influences-in-2020/ (accessed on 30 October 2021).

50. Ong, A.; Nielsen, E. Economic Impacts of COVID-19 on the Water Sector; 2020. Available online: https://www.water.org.uk/wpcontent/uploads/2020/12/Impact-of-COVID-19-on-the-water-sector_FINAL-REPORT-STC-141220.pdf (accessed on 30 October 2021).

51. Conclusions on the Response to the COVID-19 Pandemic in the EU Energy Sector-The road to Recovery-Council Conclusions (25 June 2020). Available online: https://data.consilium.europa.eu/doc/document/ST-9133-2020-INIT/pl/pdf (accessed on 26 October 2021).

52. COVID 19-The Effect on the Power Sector, Power Market Review June 2020, Willis Towers Watson 2020. Available online: https: / / willistowerswatson.turtl.co/story/power-market-review-2020/ (accessed on 10 November 2021).

53. Nauman, B. COVID-19-The Effect on the Power Sector, Power Market Review. 2020. Available online: https:/ /www.willistowe rswatson.com/assets/pdf/WTW440992_REPORT_Power-Market-Review_May-2020Master-v10.pdf (accessed on 10 November 2021).

54. Pronońska, K. Energy security and climate and energy policy under the COVID-19 pandemic. Rocz. Strateg. 2020, 26, 156-171. Available online: https://wnpism.uw.edu.pl/wp-content/uploads/2021/07/Proninska_Bezpieczenstwo_energetyczne.pdf (accessed on 10 November 2021).

55. Act of April 10, 1997 on Energy Law. J. Laws. 2021; Item 2269. Available online: https://isap.sejm.gov.pl/isap.nsf/download.xsp /WDU19970540348/U /D19970348Lj.pdf (accessed on 5 February 2021).

56. The Energy Regulatory Office. (29 June 2020). Available online: https://www.ure.gov.pl/pl/energia-elektryczna/charakterystyk a-rynku/9659,2020.html (accessed on 29 June 2021).

57. Management Board Report on the Group's Activities; ENEA: Poznan, Poland, 2019; Available online: https://pap-mediaroom.pl/sit es/default/files/attachments/202006/DOC.20200604.36302589.Report_of_the_Management_Board_on_the_operations_of_ ENEA_S.A._and_ENEA_Group_in.pdf (accessed on 20 June 2021).

58. Law on Amendments to the Excise Tax Law and Certain Other Laws, Act of 28 December 2018; Item 2538; 2018. Available online: https:/ /isap.sejm.gov.pl/isap.nsf/download.xsp/WDU20180002538/U/D20182538Lj.pdf (accessed on 5 February 2021).

59. Current Report No 29; ENEA: Poznan, Poland. 2016. Available online: https://ir.enea.pl/pr/327994/zatwierdzenie-strategii-roz woju-grupy-kapitalowej-enea-w-perspektywie-do-2030-roku (accessed on 20 June 2021).

60. Consolidated Financial Statements of Zespół Elektrowni Pątnów-Adamów-Konin for the Year 2019. Significant Events after the Balance Sheet Date. 2020. Available online: https://ri.zepak.com.pl/upload/files/ZEPAK_2019-R_Skonsolidowane_Sprawozda nie_Finansowe-sig-sig-sig-sig-sig-sig.pdf (accessed on 9 May 2021).

61. Consolidated Financial Statements of PGE for the Year 2020; Polska Grupa Energetyczna Spółka Akcyjna: 2021. Available online: https://www.gkpge.pl/Relacje-inwestorskie/dane-finansowe/2020\#tab-Q4 (accessed on 9 May 2021).

62. Consolidated Financial Statements Prepared in Accordance with EU IFRS for the Financial Year Ended 31 December 2020; Impact of the COVID-19 Pandemic. ENEA SA. 2021. Available online: https://ir.enea.pl/pr/656145/raport-roczny-rr-2020 (accessed on 2 April 2021).

63. Consolidated Financial Statements Prepared in Accordance with IFRS EU for the Financial Year Ending on 31 December 2019 ENEA SA. 2020. Available online: https:/ /ir.enea.pl/pr/521986/skonsolidowany-raport-roczny-rs-2019 (accessed on 2 April 2021).

64. Consolidated Financial Statements of the Tauron Capital Group for the Year 2020; Note 51; Taron SA: 2021. Available online: https://www.tauron.pl/tauron/relacje-inwestorskie/raporty-okresowe (accessed on 2 April 2021).

65. Consolidated Financial Statements of PGE for the Year 2019; Polska Grupa Energetyczna Spółka Akcyjna: Warsaw, Poland. 2020. Available online: https:/ / www.gkpge.pl/Relacje-inwestorskie/dane-finansowe/2019\#tab-Q4 (accessed on 9 May 2021).

66. Consolidated Financial Statements of Zespół Elektrowni Pątnów-Adamów-Konin for the Year 2020. Significant Events after the Balance Sheet Date. 2021. Available online: https://ri.zepak.com.pl/upload/files/ZEPAK_2020-R_Sprawozdanie_Finansowe-s ig-sig-sig-sig-sig-sig_2.pdf (accessed on 9 May 2021). 